Article

\title{
Constrained Dipeptide Surrogates: 5- and 7-Hydroxy Indolizidin-2-one Amino Acid Synthesis from Iodolactonization of Dehydro-2,8-diamino Azelates
}

\author{
Ramakotaiah Mulamreddy (D) and William D. Lubell *(D) \\ Département de Chimie, Université de Montréal, C.P. 6128 Succursale Centre-Ville, \\ Montreal, QC H3C 3J7, Canada; ramakotaiah.mulamreddy@umontreal.ca \\ * Correspondence: william.lubell@umontreal.ca
}

check for updates

Citation: Mulamreddy, R.; Lubell,

W.D. Constrained Dipeptide

Surrogates: 5- and 7-Hydroxy

Indolizidin-2-one Amino Acid

Synthesis from Iodolactonization of

Dehydro-2,8-diamino Azelates.

Molecules 2022, 27, 67. https://

doi.org/10.3390/molecules27010067

Academic Editor: Roman Dembinski

Received: 1 December 2021

Accepted: 17 December 2021

Published: 23 December 2021

Publisher's Note: MDPI stays neutral with regard to jurisdictional claims in published maps and institutional affiliations.

Copyright: (c) 2021 by the authors. Licensee MDPI, Basel, Switzerland. This article is an open access article distributed under the terms and conditions of the Creative Commons Attribution (CC BY) license (https:// creativecommons.org/licenses/by/ $4.0 /)$.

\begin{abstract}
The constrained dipeptide surrogates 5- and 7-hydroxy indolizidin-2-one $N$-(Boc)amino acids have been synthesized from L-serine as a chiral educt. A linear precursor $\Delta^{4}$-unsaturated $(2 S, 8 S)$-2,8-bis[N-(Boc)amino]azelic acid was prepared in five steps from L-serine. Although epoxidation and dihydroxylation pathways gave mixtures of hydroxy indolizidin-2-one diastereomers, iodolactonization of the $\Delta^{4}$-azelate stereoselectively delivered a lactone iodide from which separable (5S)- and (7S)-hydroxy indolizidin-2-one $N$-(Boc)amino esters were synthesized by sequences featuring intramolecular iodide displacement and lactam formation. X-ray analysis of the (7S)-hydroxy indolizidin-2-one $N$-(Boc)amino ester indicated that the backbone dihedral angles embedded in the bicyclic ring system resembled those of the central residues of an ideal type II' $\beta$-turn indicating the potential for peptide mimicry.
\end{abstract}

Keywords: indolizidin-2-one amino acids; peptide mimic; iodolactonization; lactam; heterocycle

\section{Introduction}

In peptide science, conformationally constrained dipeptides serve effectively as tools for structure-activity relationship studies to identify biologically active conformers [1-20]. Among approaches for creating constrained dipeptides that employ steric [2,3], stereoelectronic [4,5], and covalent constraints [1,5-21], the use of azabicyclo[X.Y.0]alkanone amino acids offers unique potential for locking the polyamide backbone into specific orientations that may mimic natural secondary structures such as $\beta$-turns. Among such bicyclic systems, the azabicyclo[4.3.0]alkanone amino acids, so-called indolizidine-2-one amino acid ( $\left.\mathrm{I}^{2} \mathrm{aa}\right)$ analogs and their ring-substituted derivatives (e.g., 1-3, Figure 1), are among the most studied for utility in dissecting the backbone geometry and side chain alignment responsible for peptide activity towards the development of receptor ligands (e.g., 4) and enzyme inhibitors (e.g., 5-7) [9-21].

Several synthetic methods have been developed to introduce substituents at the 5and 7-positions along the $\mathrm{I}^{2}$ aa ring system (Figure 1) [9-19]. For example, 5-hydroxy-5phenyl $\mathrm{I}^{2}$ aa analogs were synthesized by diastereoselective photochemical cyclization of carbamate-protected $\beta$-benzoylalaninyl prolinates [13]. A 5-chloro methyl $\mathrm{I}^{2}$ aa derivative was synthesized by the treatment of phthalimido allylglycinyl 5-methoxyprolinate with $\mathrm{TiCl}_{4}$ in 64\% yield [14]. Furthermore, 5-hydroxymethyl, 5-azidomethyl, 5-formyl, 5-carboxy, 5-benzyl, 7-hydroxymethyl, 7-hydroxypropyl, 7-azidopropyl and 7-benzyl, as well as 5,7dibenzyl $\mathrm{I}^{2}$ aa derivatives were all synthesized diastereoselectively by routes featuring, respectively, intramolecular displacements and reductive aminations of 4-substituted 5methanesulfonyl and 5-keto 2,8-diaminoazelates to form 5-substituted prolines, which reacted in lactam cyclization [10-12]. Furthermore, 5-iodo $\mathrm{I}^{2}$ aa diastereomers were respectively prepared by transannular iodolactamization of hexahydro-1H-azonines [15]. Iodide elimination afforded the corresponding $\Delta^{5}$-indolizidine-2-one, which was subsequently arylated at the 5-position by oxidative Heck chemistry [16]. In addition, 7-hydroxyethyl, 
7-azidoethyl, 7-carboxymethyl, and 7-guanidinylethyl I²aas have been synthesized from routes commencing with allylation of glutamic acid [17,22], and utilized in a program towards the development of $\alpha_{\mathrm{v}} \beta_{3}$ and $\alpha_{\mathrm{v}} \beta_{5}$ integrin receptor ligands [18].<smiles>[R]OC1CC[C@H]2[C@@H]([Y])C[C@H](NC(=O)O)C(=O)N12</smiles>

$(3 S, 6 R, 9 S)-1: \mathrm{X}=\mathrm{R}=\mathrm{H}$ $(3 S, 5 S, 6 S, 9 S)-2: X=O H, R=H$ $(3 S, 5 S, 6 S, 9 S)-8: X=O H, R=\mathrm{CH}_{3}$<smiles>O=C(Cc1c[nH]c2ccccc12)N[C@H]1C[C@@H](OCc2ccccc2)[C@@H]2CC[C@@H](C(=O)Nc3ccccc3)N2C1=O</smiles><smiles>[R]OC1CC([X])C2CC[C@H](NC(=O)O)C(=O)N12</smiles>

$(3 S, 6 S, 9 S)-1: X=R=H$ $(3 S, 6 S, 7 S, 9 S)-3: X=O H, R=H$ $(3 S, 6 S, 7 S, 9 S)-9: X=O H, R=\mathrm{CH}_{3}$<smiles>[R]C[C@]1(N)C[C@H](OC)[C@H]2[C@@H](CC)C[C@H](C(=O)NCc3ccc(C(N)=NCl)cc3)N2C1=O</smiles>

Figure 1. Indolizidine-2-one amino acid (Boc- $\mathrm{I}^{2}$ aa-OH) isomers 1, 5- and 7-hydroxy $\mathrm{I}^{2}$ aas 2 and 3, methyl ester counterparts 8 and $\mathbf{9}$, and biologically active 5- and 7-substituted $\mathrm{I}^{2}$ aa NK-2 ligand 4 and thrombin inhibitors 5-7.

The Hanessian laboratory has played an instrumental role in demonstrating the value of 5- and 7-substituted $\mathrm{I}^{2}$ aa residues in the study of biologically active peptide receptors [19-21]. For example, 5-benzyloxy $\mathrm{I}^{2}$ aa 4 was designed by Hanessian and shown to be a weak but selective antagonist of the tachykinin NK-2 (neurokinin-2) receptor [19]. Furthermore, 3,5,7-trisubstituted I ${ }^{2}$ aas 5-7 were designed, synthesized, and shown to act as potent thrombin [Factor IIa] and Factor VIIa inhibitors exhibiting selectivity over plasmin and Factor XIa [20]. Substituted I $I^{2}$ aa peptides 4-7 were respectively synthesized from pyroglutamate by routes featuring the addition of 2-trimethylsilyloxy furan onto an iminium ion intermediate, followed by lactone to lactam ring expansion to obtain the corresponding 5-hydroxy 9-silyloxymethyl indolizidine-2-one [19-21]. Subsequent installation of the amine and alkyl substituents at the 3-position and hydroxymethyl group oxidation at the 9-position gave the 3-azido indolizidine-2-one 9-carboxylate counterparts, which were introduced into the peptide mimic structures [19-21]. Validating their utility for peptide-based medicinal chemistry, the herculean research of the Hanessian laboratory has illustrated the necessity for effective synthetic routes to access 5- and 7-substituted $\mathrm{I}^{2}$ aa residues.

Streamlined syntheses of 5- and 7-hydroxy indolizidine-2-one $\mathrm{N}$-(Boc)amino acids 2 and 3 are now reported by methods employing L-serine as a chiral educt. Motivated by the research of the Jackson laboratory in which $(2 S, 8 S)$-1,9-dibenzyl $\Delta^{4}$-2,8-bis[N(Boc)amino]azelate was prepared by the copper-catalyzed $\mathrm{S}_{\mathrm{N}} 2^{\prime}$ reaction of the zincate derived from $N$-(Boc)- $\beta$-iodo alanine benzyl ester onto ( $E$ )-1,3-dichloroprop-1-ene [23], a series of related $\Delta^{4}$-2,8-diaminoazelates were synthesized and studied in different olefin oxidation chemistries to prepare intermediates towards the hydroxy indolizidine-2-one structures. Among different oxidation approaches yielding access to 5-hydroxy and 7-hydroxy $I^{2}$ aa derivatives, useful routes to $(3 S, 5 S, 6 S, 9 S)-2$ and $(3 S, 6 S, 7 S, 9 S)-3$ were conceived by way of diastereoselective iodolactonization chemistry inspired by the seminal research of the Bartlett laboratory [24]. 


\section{Results and Discussion}

Initially, 5- and 7-hydroxy indolizidine-2-one $N$-(Boc)amino esters 8 and 9 were pursued by pathways featuring a ring opening of 4-oxiranyl-2,8-diaminoazelates. Oxiranes 12a-c were synthesized by epoxidation of $\Delta^{4}-2,8$-diaminoazelates $11 \mathbf{a}-\mathbf{c}$, which were respectively prepared from (E)-1,3-dichloroprop-1-ene by copper catalyzed $\mathrm{S}_{\mathrm{N}} 2^{\prime}$ additions of zincates derived from methyl $\beta$-iodo alaninates 12a-c protected with Boc [25], Cbz [26], and Fmoc groups (Scheme 1) [27]. Although the $15 \mathrm{~Hz}$ coupling constant suggested the formation of the E-trans olefins $\mathbf{1 1 a}$ and $\mathbf{1 1} \mathbf{b}$, without the corresponding Z-cis isomer, NOESY experiments were performed to confirm the double-bond geometry. The E-geometry of olefins 11a and 11b was ascertained by NOESY experiments in which the long-range through-space transfer of magnetization was observed, respectively, between the vinyl C4 (5.38 and $5.35 \mathrm{ppm}$ ) and allylic C6 protons (2.09 and 2.07 ppm) and between the vinyl C5 (5.51 and $5.48 \mathrm{ppm}$ ) and allylic C3 protons (2.47 and $2.50 \mathrm{ppm}$ ) (Scheme 1). No nuclear Overhauser effect was observed between the two vinyl protons nor between the two sets of allylic protons.
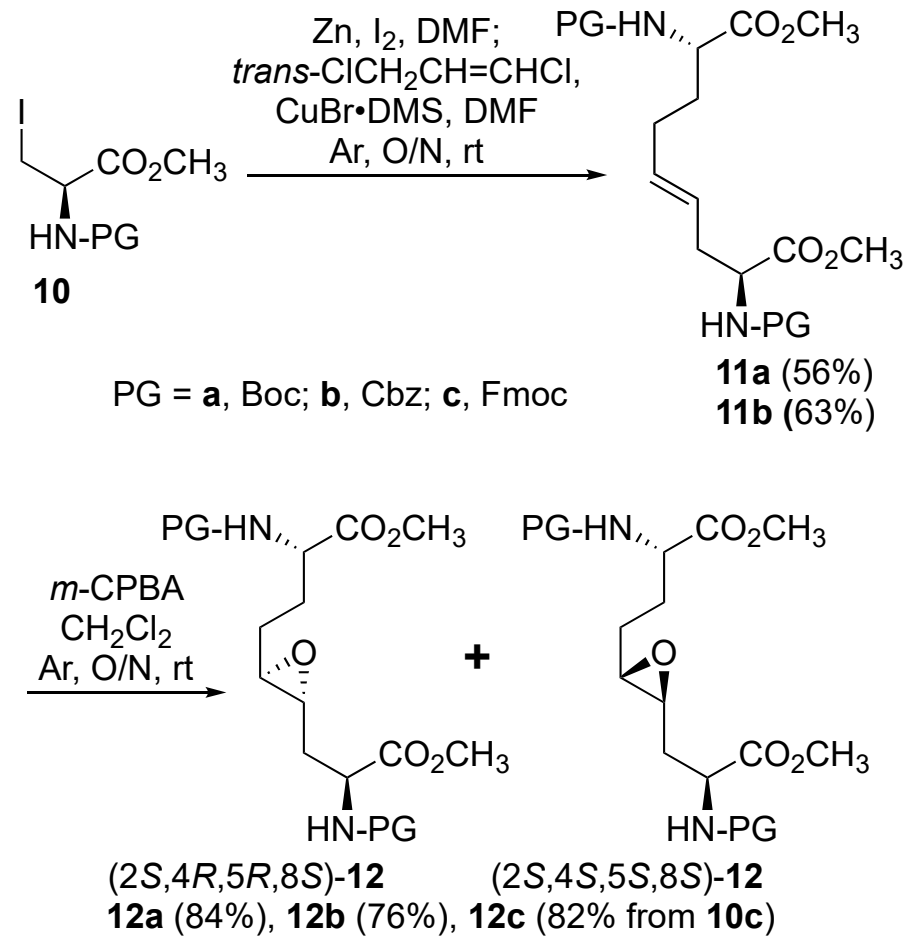

Scheme 1. Synthesis of protected epoxides 12.

Previously, epoxidations of N-Boc and N-Cbz allyl- and homoallyl-glycine esters with $m$-chloroperbenzoic acid ( $m$-CPBA) in dichloromethane had given 1:1 diastereomeric mixtures of the corresponding oxiranes, which were inseparable by chromatography [28-30]. The C3-protons of benzyl (2S,4RS)-2-(Boc)amino-3-(2-oxiranyl)propionate was reported to exhibit a doubling of signals in the ${ }^{1} \mathrm{H}$ NMR spectrum [28]. The appearance of multiple sets of signals for the two possible isomers was similarly observed in the spectra of inseparable epoxide diastereomers 12a-c and validated by COSY spectra of the Cbz and Fmoc analogs $\mathbf{1 2 b}$ and 12c in which through-bond couplings between two sets of C3-protons with two overlapping downfield $\alpha-(\mathrm{C} 2)$-proton signals were observed. Oxiranes 12a-c were thus obtained as 1:1 diastereomeric mixtures, which were used in the subsequent chemistry.

Based on the successful synthesis of 6-hydroxymethyl $\mathrm{I}^{2}$ aa diastereomers in which 5-hydroxymethyl prolines were prepared from a related C2 symmetric oxirane using Lewisacid activation with $\mathrm{BF}_{3} \cdot \mathrm{Et}_{2} \mathrm{O}$ in $\mathrm{DCM}$ at $-78{ }^{\circ} \mathrm{C}$ [31], similar conditions were employed for the intramolecular ring-opening of epoxide 12a (Scheme 2). Multiple isomers of the 
material with a molecular ion corresponding to proline 13 and hydroxyproline 14 were obtained from oxirane 12a likely by endo and exo ring openings by the attack of the two different carbamate-protected nitrogen $[28,32,33]$. Considering that the isomeric mix could be due, in part, to carbocation intermediates formed under the Lewis acid conditions, a method to remove the Boc group without the ring opening of the epoxide was attempted featuring heating oxirane 12a in water at reflux [34]. Deprotection of the Boc group, intramolecular epoxide ring opening, and lactam formation all occurred upon treating 12a with boiling water. Amine protection with di-tert-butyl dicarbonate and triethyl amine in dichloromethane, however, afforded four isomers of 5- and 7-hydroxy $\mathrm{I}^{2}$ aa esters 8 and 9, which were observed by LCMS in a 1:1:1:1 ratio. Employing Cbz-protected epoxide $\mathbf{1 2 b}$, hydrogenolytic cleavage of the carbamate using hydrogen and palladium-on-carbon in ethanol commenced an epoxide ring opening and lactam formation sequence, which was followed by Boc protection as described above to afford four isomers of $\mathbf{8}$ and $\mathbf{9}$, which were observed in a 1:5:5:1 ratio by HPLC. The improvement in selectivity may be due to a favored exo-tet-like ring opening of the epoxide diastereomers by the free amine, which when generated at a lower temperature reacted to favor the proline instead of the hydroxyproline counterparts [32,33]. In spite the possibility of improved regioselectivity in the oxirane ring opening, the route (Scheme 2) was, however, deemed inefficient due to the complications engendered from the lack of diastereomeric selectivity in the epoxidation of olefins 11.

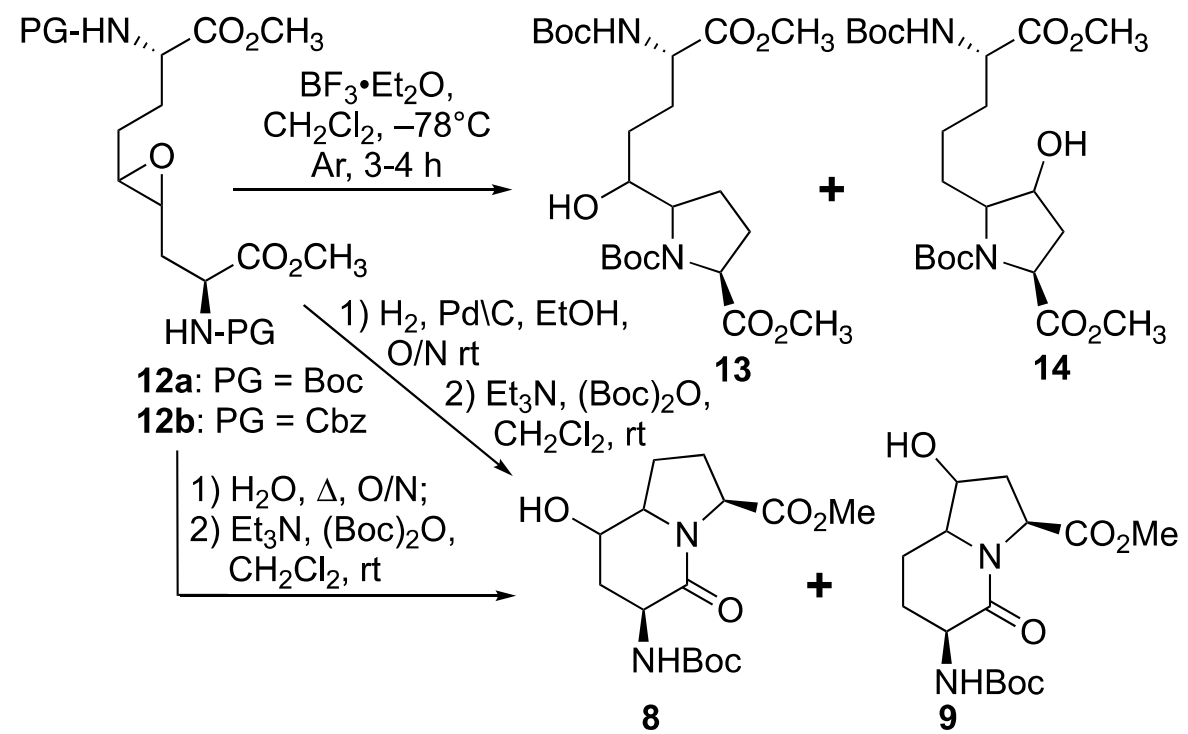

Scheme 2. Syntheses of 5- and 7-hydroxy Boc-I²aa-OMe 8 and 9 from epoxide 12.

Prompted by earlier success using transannular iodolactamization to prepare azabicyclo[X.Y.0]alkan-2-one ring systems [15,35], and related iodoamination protocols for preparing iodomethyl pyrrolidines and piperidines [36-38], $\Delta^{4}$-diaminoazelate 11a was subjected to iodine and $\mathrm{NaHCO}_{3}$ at $-20^{\circ} \mathrm{C}$ (Scheme 3). The ring opening of the iodonium intermediate by one of the two carbamate-protected nitrogen appeared to be a method for selectively obtaining proline $\mathbf{1 5}$ instead of the azetidine counterpart; however, a mixture of diastereomeric iodolactones $\mathbf{1 6}$ was also produced as a competing side product. Considering the lactone as a potential means for differentiating between the two carboxylates, dihydroxylation of $\Delta^{4}$-diaminoazelate 11a was performed using osmium tetroxide and $\mathrm{N}$-methylmorpholine $\mathrm{N}$-oxide (NMO) in aqueous acetone to provide hydroxy lactone $\mathbf{1 7}$ as a mixture of diasteromers [39]. Mesylate $\mathbf{1 8}$ was obtained by methanesulfonation of hydroxy lactone 17 using methanesulfonyl chloride and triethylamine in dichloromethane. Mesylate 18 was converted to hydroxy I $\mathrm{I}^{2}$ aa analogs 8 and 9 by a three-step sequence featuring proline formation after Boc group removal with $\mathrm{HCl}$ gas bubbles in dichloromethane, lactam cyclization upon treatment of the hydrochloride salt with triethylamine in methanol 
at reflux, and amine protection with di-tert-butyl decarbonate in dichloromethane. The HPLC chromatogram of the products from this sequence exhibited four peaks with molecular ions corresponding to 5- and 7-hydroxy Boc- $\mathrm{I}^{2}$ aa-OMe isomers $\mathbf{8}$ and $\mathbf{9}$ (Scheme 3) in a 1:1:1:1 ratio.

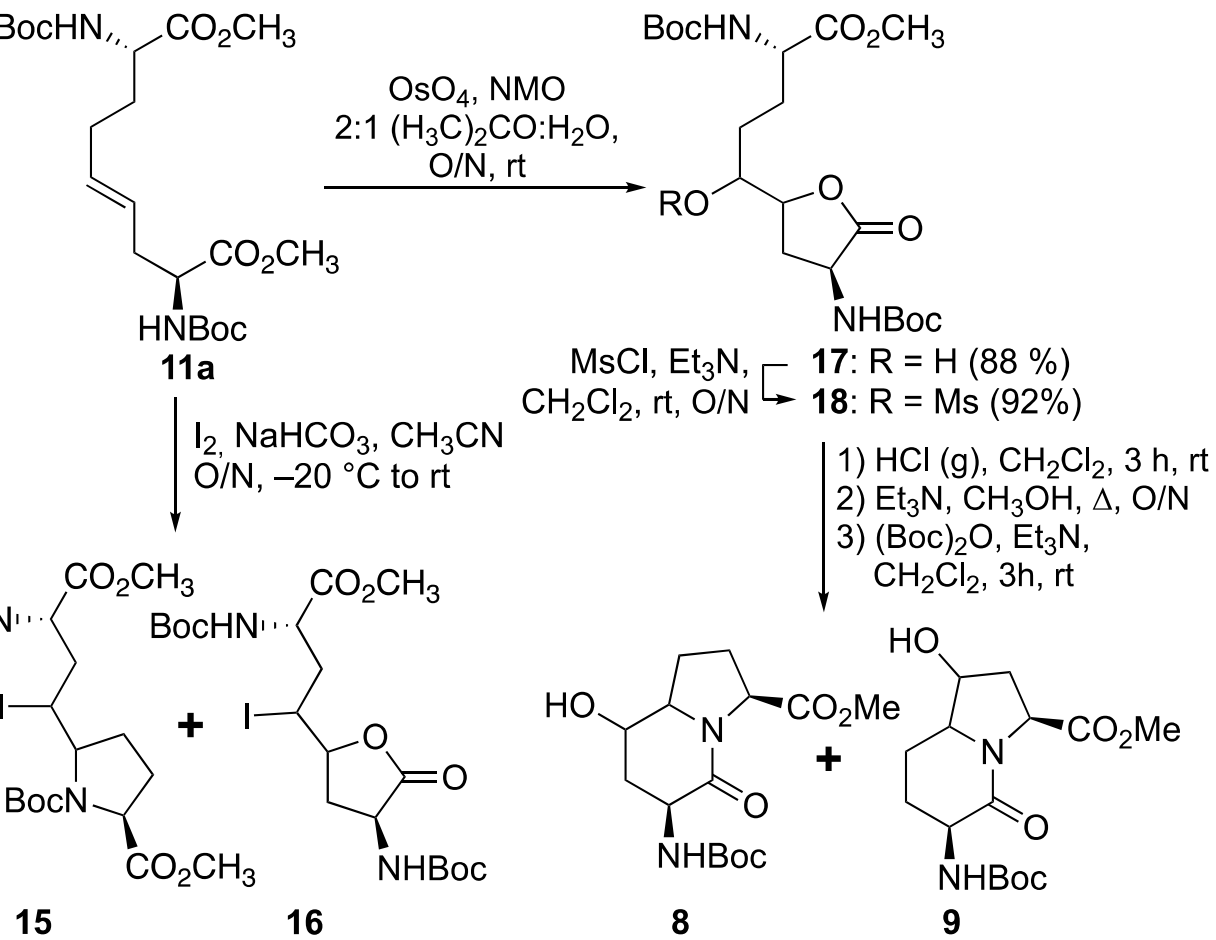

Scheme 3. Strategies featuring iodoamination and dihydroxylation of $\Delta^{4}$-diaminoazelate 11a.

Different mixtures of 5- and 7-hydroxy Boc- $\mathrm{I}^{2}$ aa-OMe diastereomers 8 and 9 likely arose from a combination of a lack of facial selectivity in the epoxidation and the dihydroxylation of olefin $\mathbf{1 1}$ and competing nucleophilic attack from both nitrogen of diamino azelate epoxide $\mathbf{1 2}$ and methanesulfonate 18. The loss of stereochemical integrity may also arise from competing $S_{N} 1$ processes due to the epoxide ring opening prior to pyrrolidine formation. Intrigued by the production of iodolactone $\mathbf{1 6}$ as a side product from the iodoamination strategy, an iodolactonization approach was considered because of the high facial selectivity achieved on simpler $\gamma, \delta$-unsaturated carboxylic acids $[24,40,41]$.

After saponification of diester 11a with lithium hydroxide in aqueous dioxane, dicarboxylic acid 19 was treated with cesium carbonate and iodine in an ice-cold acetonitrile solution (Scheme 4). Analysis by LCMS demonstrated a major peak with a molecular ion corresponding to lactone 20. Subsequent treatment with iodomethane and potassium carbonate in DMF furnished the corresponding methyl ester tetrahydrofuran-2-one $\left(1^{\prime} R, 5 S\right)-16$ after chromatography in 55\% yield from diacid acid 19. Attempts to perform the iodolactonization without a base gave a product mostly from the loss of Boc protection. Employing the same three-step sequence described above to convert methane sulfonate $\mathbf{1 8}$ into esters 8 and $\mathbf{9}$, iodide $\left(1^{\prime} R, 5 S\right)$-16 was transformed into separable 5- and 7-hydroxy $\mathrm{I}^{2}$ aa esters $(5 S, 6 S)-8$ and $(6 S, 7 S)-\mathbf{9}$ in $42 \%$ and $34 \%$ overall yields, respectively. Subsequent saponification of esters (5S,6S)-8 and (6S,7S)-9 gave, respectively, the acids $(5 S, 6 S)-2$ and $(6 S, 7 S)-3$ in $64 \%$ and $78 \%$ yields. 
<smiles>COC(=O)[C@H](CC=CCC[C@H](NC(=O)OC(C)(C)C)C(=O)OCc1ccccc1)C(=O)OCc1ccccc1</smiles>

11a

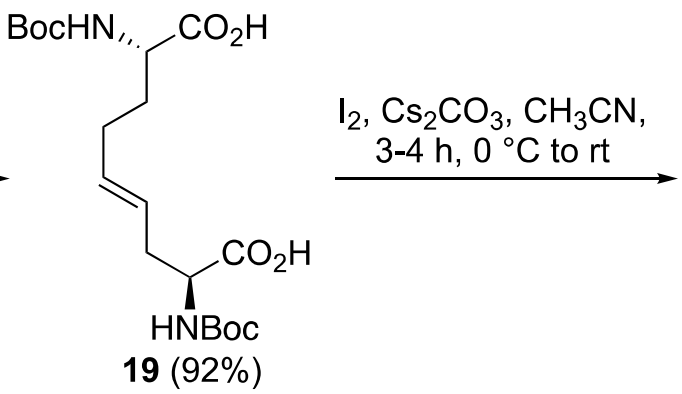

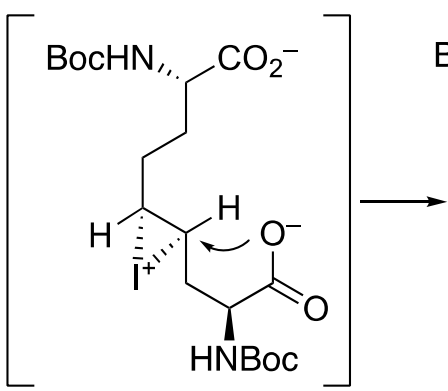<smiles>CC(C)(C)OC(=O)N[C@@H](CC[C@H](I)C1C[C@H](N)C(=O)O1)C(=O)O</smiles>

20

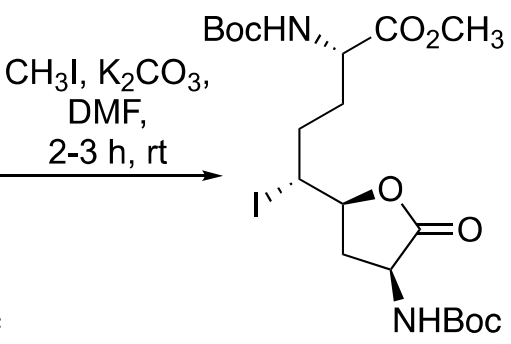

$\left(1^{\prime} R, 4^{\prime} S, 3 S, 5 S\right)-16(55 \%)$

1) $\mathrm{HCl}(\mathrm{g}), \mathrm{CH}_{2} \mathrm{Cl}_{2}, 2-3 \mathrm{~h}, \mathrm{rt}$

2) $\mathrm{Et}_{3} \mathrm{~N}, \mathrm{MeOH}, \Delta, \mathrm{O} / \mathrm{N}$

3) $(\mathrm{Boc})_{2} \mathrm{O}, \mathrm{Et}_{3} \mathrm{~N}$, $\mathrm{CH}_{2} \mathrm{Cl}_{2}, 3 \mathrm{~h}, \mathrm{rt}$

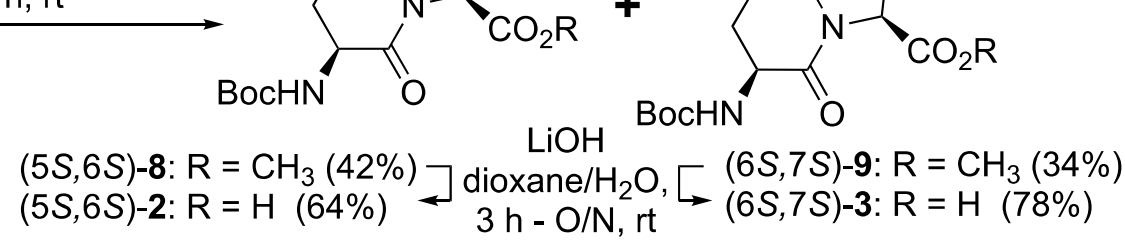

Scheme 4. Synthesis of 5- and 7- hydroxy $\mathrm{I}^{2}$ aa derivatives 2 and 3.

Assignment of Regio-Chemistry and Stereochemistry of 5- and 7-Hydroxy I ${ }^{2}$ aa Esters

The configuration of the ring fusion and hydroxyl group carbons of the 5- and 7hydroxy $\mathrm{I}^{2}$ aa esters $\mathbf{8}$ and $\mathbf{9}$, as well as the alcohol position on the ring system, were all assigned based on two-dimensional NMR spectroscopic experiments. The locations of the indolizidine-2-one ring protons were initially assigned by COSY experiments in which through-bond couplings were used to trace the sequence from the downfield shifted carbamate $\mathrm{NH}$ to the $\mathrm{C} 9$ hydrogen. Subsequently, heteronuclear single quantum coherence (HSQC) spectroscopy was used to correlate the protons linked to similar carbons. The $\beta$-protons on the same face as the C3 carbamate and C9 carboxylate appeared generally up-field of their $\alpha$-counterparts due to anisotropic effects caused by the latter functional groups [42]. Finally, relative configurations were ascertained (Figure 2) based on NOESY experiments in which the observed through-space transfers of magnetization were used to correlate the stereochemical assignments. 


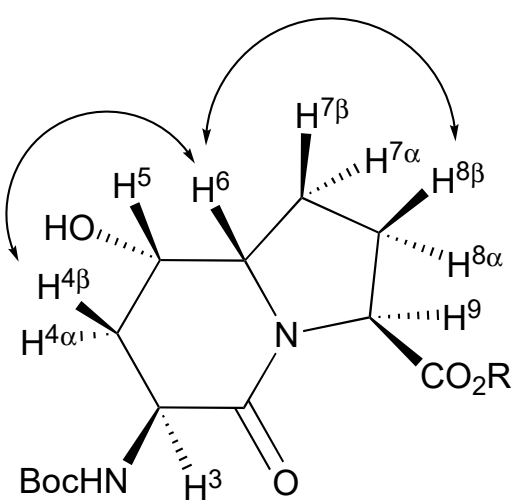

$(5 S, 6 S)-8$

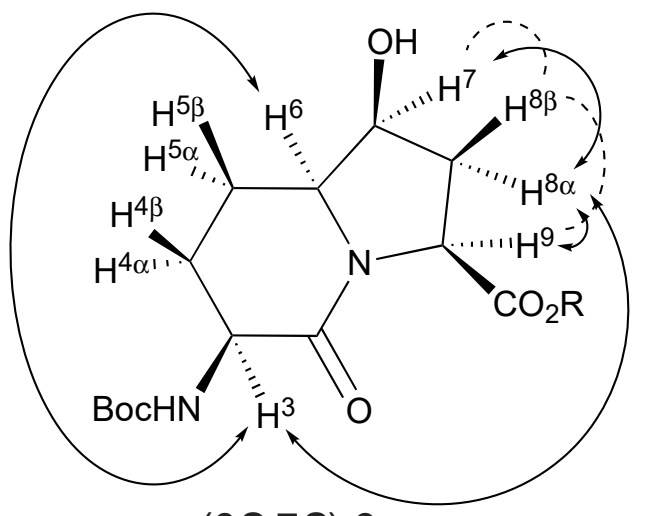

$(6 S, 7 S)-9$

Figure 2. Strong (solid double-tipped arrows) and weak (dotted lines) through-space transfer of magnetization used to assign relative stereochemistry of $(5 S, 6 S)-\mathbf{8}$ and $(6 S, 7 S)-\mathbf{9}$.

The ring fusion protons (3.88 and $3.74 \mathrm{ppm}$ ) of 5- and 7-hydroxy Boc- $\mathrm{I}^{2}$ aa-OMe $(5 S, 6 S)$ 8 and $(6 S, 7 S)-9$ were respectively assigned the $S$ stereochemistry based on nuclear Overhauser effects (nOe) with the $C 4 \beta$ and $C 8 \beta$ protons (1.99 and $1.84 \mathrm{ppm}$ ) and with the $\mathrm{C} 3$ proton (4.13 ppm, Figure 2). No long-range through-space transfer of magnetization was observed for the protons on the alcohol-bearing carbons. In the case of $(6 S, 7 S)-9$, the relative nOe between the $\mathrm{C} 7$ proton was stronger for the $\mathrm{C} 8 \alpha$ proton $(2.35 \mathrm{ppm}$ ) compared to that of the $\mathrm{C} 8 \beta$ proton $(2.15 \mathrm{ppm})$. The stereochemical assignments for Boc-(7-OH) $\mathrm{I}^{2} \mathrm{aa}-\mathrm{OMe}$ $(6 S, 7 S)-9$ were confirmed by $\mathrm{X}$-ray analysis as discussed below.

The configurations of the hydroxyl group in Boc- $(5-\mathrm{OH}) \mathrm{I}^{2}$ aa-OMe $(5 S, 6 S)-8$ and the iodolactone of tetrahydrofuran-2-one $\left(1^{\prime} R, 5 S\right)-16$ were based on the latter serving as a common intermediate for both the former and Boc- $(7-\mathrm{OH}) \mathrm{I}^{2}$ aa-OMe $(6 S, 7 S)-9$. The stereochemistry of the ring-fusion and alcohol carbons are respectively derived from the inversion on nitrogen attack of the iodide and retention on the lactone opening during synthesis of the bicycle. Although the order of attack of the iodine and carboxylate may proceed by a traditional iodonium intermediate (Scheme 4) [24], and by a more concerted nucleophileassisted alkene activation mechanism [43], the stereochemical outcome of iodolactone $\left(1^{\prime} R, 5 S\right)$-20 arises from the attack of iodine by the face of the olefin on the opposite side of the proximal carboxylate of $\Delta^{4}$-azelate 19 (Scheme 4 ).

The relative configurational assignments for 7-hydroxy Boc- $\mathrm{I}^{2}$ aa-OMe $(6 S, 7 S)-9$ were confirmed by $\mathrm{X}$-ray analysis of crystals grown from a dichloromethane-in-hexanes mixture (Figure 3). Two conformers differing primarily by the carbamate orientation were present in the unit cell and connected by an intermolecular hydrogen bond from the 7-hydroxyl group donor to the lactam carbonyl oxygen acceptor. Examination of the backbone dihedral angles embedded in the $\mathrm{I}^{2}$ aa ring system $\left(\psi^{\mathrm{i}+1}-172^{\circ}\right.$ and $\phi^{i+2}-78^{\circ} ; \psi^{\mathrm{i}+1}-175^{\circ}$ and $\left.\phi^{\mathrm{i}+2}-71^{\circ}\right)$ of the conformers in the X-ray structure of the 7-hydroxy analog (6S,7S)-9 indicated a close relation to those of the central residues of an ideal type II $\beta$-turn $\left(\psi^{\mathrm{i}+1}-120^{\circ}\right.$ and $\phi^{\mathrm{i}+2}-80^{\circ}$ ) [44], and to that of the methyl ester of the parent $\mathrm{I}^{2}$ aa counterpart (6S)-21 $\left(\psi^{\mathrm{i}+1}-176^{\circ}\right.$ and $\phi^{\mathrm{i}+2}-78^{\circ}$, Figure 4) [45]. Relative to the values in the crystal structure of Boc- $\mathrm{I}^{2}$ aa-OMe (6S)-21, the $\phi^{\mathrm{i}+2}$ dihedral angle was apparently less influenced by the smaller $7 \beta$-hydroxy substituent than the $7 \alpha$-hydroxymethyl substituent in Boc- $\left(7-\mathrm{HOCH}_{2}\right) \mathrm{I}^{2}$ aaOMe $\left(22, \psi^{i+1}-175^{\circ}\right.$ and $\left.\phi^{i+2}-68^{\circ}\right)[11]$. 

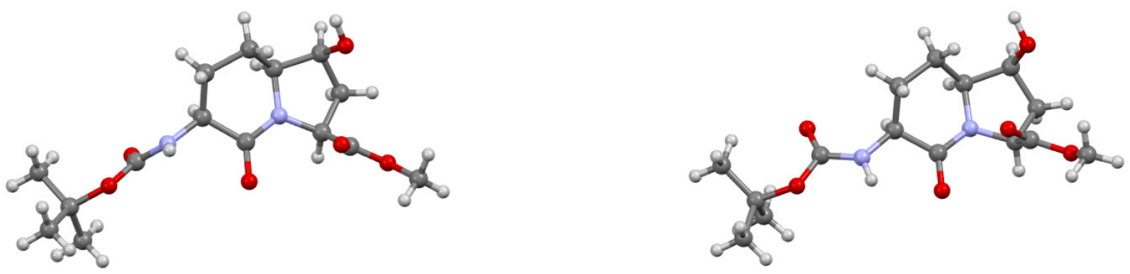

Figure 3. Depictions of conformers in the X-ray structure of (6S,7S)-9.

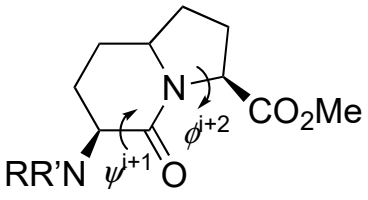

common $\mathrm{I}^{2} \mathrm{aa}$ $\left(\psi^{j+1}, \phi^{j+1}\right)$

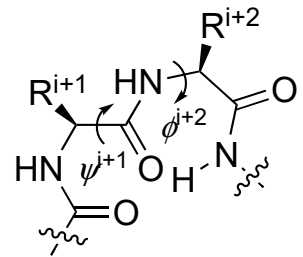

ideal type II' $\beta$-turn $\left(\psi^{j+1}=-120^{\circ}, \phi^{j+1}=-80^{\circ}\right)$

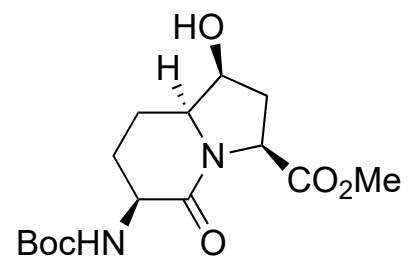

(6S.7S)-9

$\left(-172^{\circ},-78^{\circ}\right)$

$\left(-175^{\circ},-71^{\circ}\right)$<smiles>CC(=O)OC(C)C1CC[C@H]2CC[C@H](NC(C)(C)C)C(=O)N12</smiles>

$(6 S)-21$

$\left(-176^{\circ},-78^{\circ}\right)$<smiles>CC(=O)OC(C)(C)OC(=O)N1CC[C@@H]2C(CO)C[C@@H](C(=O)OCc3ccccc3)N2C1=O</smiles>

22

$\left(-175^{\circ},-68^{\circ}\right)$

Figure 4. X-ray-determined backbone dihedral angles of related $\mathrm{I}^{2}$ aa systems and an ideal type II $^{\prime}$ $\beta$-turn $[11,44,45]$.

\section{Materials and Methods}

Anhydrous solvents $\left(\mathrm{CH}_{3} \mathrm{CN}, \mathrm{DMF},\left(\mathrm{CH}_{3}\right)_{2} \mathrm{CO}, \mathrm{CH}_{2} \mathrm{Cl}_{2}\right.$, and $\left.\mathrm{CH}_{3} \mathrm{OH}\right)$ were obtained by passage through solvent filtration systems (GlassContour, Irvine, CA, USA). All reagents from commercial sources were used as received: Iodine was purchased from Aldrich (USA) and solvents were obtained from Fisher Chemical. The N-(Boc)-, (Cbz)-, and (Fmoc)-3iodo-L-alanine methyl esters $\mathbf{1 0 a}-\mathbf{c}$ were respectively prepared according to the literature methods reported in references [25-27]. Purification by silica gel chromatography was performed on 230-400 mesh silica gel; analytical thin-layer chromatography (TLC) was performed on silica gel 60 F254 (aluminum sheet) and visualized by UV absorbance or staining with $\mathrm{KMnO}_{4}$. Melting points are reported in degree Celsius $\left({ }^{\circ} \mathrm{C}\right)$, uncorrected and obtained using a Mel-Temp melting point apparatus equipped with a thermometer on the sample that was placed in a capillary tube. Spectroscopic ${ }^{1} \mathrm{H}$ and ${ }^{13} \mathrm{C}$ NMR experiments were recorded at room temperature $(298 \mathrm{~K})$ in $\mathrm{CDCl}_{3}(7.26 / 77.16 \mathrm{ppm})$, DMSO-d 6 (2.5/39.56), and $\mathrm{CD}_{3} \mathrm{OD}(3.31 / 49.0 \mathrm{ppm})$ on Bruker $\mathrm{AV}(500 / 125$, and 700/175 MHz) instruments using an internal solvent as the reference. Spectra are presented in the Supplementary Materials. Chemical shifts are reported in parts per million (ppm), and coupling constant $(J)$ values in Hertz $(\mathrm{Hz})$. Abbreviations for peak multiplicities are s (singlet), $\mathrm{d}$ (doublet), $\mathrm{t}$ (triplet), q (quadruplet), q (quintuplet), m (multiplet), and br (broad). Certain ${ }^{13} \mathrm{C} \mathrm{NMR}$ chemical shift values were extracted from HSQC spectra. High-resolution mass spectrometry (HRMS) data were obtained on an LC-MSD instrument in electrospray ionization (ESI-TOF) mode by the Centre Régional de Spectrométrie de Masse de 1'Université de Montréal. Either protonated molecular ions $[\mathrm{M}+\mathrm{H}]^{+}$or sodium adducts $[\mathrm{M}+\mathrm{Na}]^{+}$were used for empirical formula confirmation. Infrared spectra were recorded in the neat on a Perkin Elmer Spectrometer FT-IR instrument, and are reported in reciprocal centimeters $\left(\mathrm{cm}^{-1}\right)$. The X-ray structure was solved using a Bruker Venture Metaljet diffractometer by 
the Laboratoire de diffraction des rayons $X$ de l'Université de Montréal. Specific rotations $[\alpha]_{\mathrm{D}}$ were measured at $25^{\circ} \mathrm{C}$ at the specified concentrations $(c$ in $\mathrm{g} / 100 \mathrm{~mL})$ using a $0.5 \mathrm{dm}$ cell on a PerkinElmer Polarimeter 589 instrument and expressed using the general formula $[\alpha]_{\mathrm{D}}^{25}=(100 \times \alpha) /(\mathrm{d} \times c)$.

\section{1. (3S,5S,6S,9S)-3-N-(Boc)amino-5-hydroxy-indolizin-2-one-9-carboxylic Acid [(3S,5S,6S,9S)-2]}

A $0{ }^{\circ} \mathrm{C}$ solution of ester $(3 S, 5 S, 6 S, 9 S)-8(15 \mathrm{mg}, 0.046 \mathrm{mmol})$ in 1,4-dioxane $(0.5 \mathrm{~mL})$ was treated with a $1 \mathrm{~N}$ solution of $\mathrm{LiOH}(1.9 \mathrm{mg}, 0.046 \mathrm{mmol}, 1$ equiv.). The cooling bath was removed. The reaction mixture was warmed to room temperature with stirring overnight, at which time TLC indicated the consumption of the starting material. The volatiles were evaporated under reduced pressure. The residue was partitioned between $\mathrm{H}_{2} \mathrm{O}(5 \mathrm{~mL})$ and ethyl acetate $(5 \mathrm{~mL})$. The aqueous phase was acidified with $1 \mathrm{~N} \mathrm{HCl}$ to $\mathrm{pH} 3$ and extracted with ethyl acetate $(3 \times 10 \mathrm{~mL})$. The organic extractions were combined, dried with $\mathrm{Na}_{2} \mathrm{SO}_{4}$, filtered, and concentrated under vacuum to afford (3S,5S,6S,9S)-2 (9 mg, 64\%) as a white foam; $[\alpha]_{\mathrm{D}}{ }^{25}-10.2\left(c 0.32, \mathrm{CHCl}_{3}\right) ;{ }^{1} \mathrm{H} \mathrm{NMR}\left(500 \mathrm{MHz}, \mathrm{CDCl}_{3}\right): \delta 5.39$ (s, br, $\left.1 \mathrm{H}\right), 4.71$ (s, $1 \mathrm{H}), 4.39$ (s, br, 1H), 4.29-4.28 (m, 1H), 3.84-3.80 (m, 1H), 2.6-2.52 (m, 1H), 2.39-2.33 (m, $2 \mathrm{H}), 2.26-2.20(\mathrm{~m}, 1 \mathrm{H}), 2.05-2.02(\mathrm{~m}, 1 \mathrm{H}), 2.0-1.95(\mathrm{~m}, 1 \mathrm{H}), 1.67-1.63(\mathrm{~m}, 1 \mathrm{H}), 1.47(\mathrm{~s}, 9 \mathrm{H})$; ${ }^{13} \mathrm{C}\left\{{ }^{1} \mathrm{H}\right\} \mathrm{NMR}\left(125 \mathrm{MHz}, \mathrm{CDCl}_{3}\right) \delta 172.0,167.3,147.3,80.5,64.0,60.0,35.2,32.0,30.0,28.3$, 26.1, 23.0; FT-IR (neat) $v_{\max } 3328,2919,1702,1521,1449,1362,1208,1166,1050,1031 \mathrm{~cm}^{-1}$; HRMS (ESI-TOF) $m / z[\mathrm{M}+\mathrm{Na}]^{+}$calcd for $\mathrm{C}_{14} \mathrm{H}_{22} \mathrm{~N}_{2} \mathrm{O}_{6} \mathrm{Na} 337.1370$, found 337.1374.<smiles>O=C(O)N[C@H]1C[C@@H](O)[C@H]2CC[C@@H](C(=O)O)N2C1=O</smiles>

(3S,5S,6S,9S)-2

\section{2. (3S,6S,7S,9S)-3-N-(Boc)amino-7-hydroxy-indolizin-2-one-9-carboxylic Acid [(3S,6S,7S,9S)-3]}

A $0{ }^{\circ} \mathrm{C}$ solution of ester $(3 S, 6 S, 7 S, 9 S)-9(150 \mathrm{mg}, 0.46 \mathrm{mmol})$ in 1,4-dioxane $(5 \mathrm{~mL})$ was treated with a $1 \mathrm{~N}$ solution of $\mathrm{LiOH}(19.2 \mathrm{mg}, 0.46 \mathrm{mmol}, 1$ equiv.). The cooling bath was removed. The reaction mixture was warmed to room temperature with stirring for $3 \mathrm{~h}$, at which time TLC indicated the consumption of the starting material. The volatiles were evaporated under reduced pressure. The residue was partitioned between $\mathrm{H}_{2} \mathrm{O}$ $(10 \mathrm{~mL})$ and ethyl acetate $(5 \mathrm{~mL})$. The aqueous phase was acidified with $1 \mathrm{~N} \mathrm{HCl}$ to $\mathrm{pH}$ 3 and extracted with ethyl acetate $(3 \times 10 \mathrm{~mL})$. The organic extractions were combined, dried with $\mathrm{Na}_{2} \mathrm{SO}_{4}$, filtered, and concentrated under vacuum to afford $(3 S, 6 S, 7 S, 9 S)-3$ (112 mg, 78\%) as a white solid: $\mathrm{mp} 105-106{ }^{\circ} \mathrm{C} ;[\alpha]_{\mathrm{D}}{ }^{25}-19.13\left(c 0.23, \mathrm{CHCl}_{3}\right) ;{ }^{1} \mathrm{H}$ NMR (500 MHz, CD 3 OD): $\delta 4.460-4.43(\mathrm{dd}, J=9.3,4.3 \mathrm{~Hz}, 1 \mathrm{H}), 4.26-4.24(\mathrm{~m}, 1 \mathrm{H}), 4.22-4.17(\mathrm{~m}$, $1 \mathrm{H}), 3.76-3.72(\mathrm{~m}, 1 \mathrm{H}), 2.47-2.41(\mathrm{~m}, 1 \mathrm{H}), 2.21-2.18(\mathrm{~d}, J=14.2 \mathrm{~Hz}, 1 \mathrm{H}), 2.15-2.07(\mathrm{~m}, 2 \mathrm{H})$, 1.87-1.82 (m, 2H), $1.48(\mathrm{~s}, 9 \mathrm{H}) ;{ }^{13} \mathrm{C}\left\{{ }^{1} \mathrm{H}\right\}$ NMR (125 MHz, CD $\mathrm{CDD}_{3} \delta 174.0,170.0,156.6,79.1$, 71.2, 62.3, 57.2, 50.0, 37.0, 27.3, 27.0, 19.0; FT-IR (neat) $v_{\max } 3325,2922,1697,1523,1451,1365$, $1211,1162,1055,1032 \mathrm{~cm}^{-1}$; HRMS (ESI-TOF) $\mathrm{m} / z[\mathrm{M}+\mathrm{Na}]^{+}$calcd for $\mathrm{C}_{14} \mathrm{H}_{22} \mathrm{~N}_{2} \mathrm{O}_{6} \mathrm{Na}$ 337.1370, found 337.1374 . 
<smiles>O=C(O)[NH2+][C@@H]1CC[C@@H]2[C@H](O)C[C@@H](C(=O)O)N2C1=O</smiles>

$(3 S, 6 S, 7 S, 9 S)-3$

3.3. Methyl (3S,5S,6S,9S)-3-N-(Boc)amino)-5-hydroxy-indolizin-2-one-9-carboxylate and (3S,6S,7S,9S)-3-N-(Boc)amino)-7-hydroxy-indolizin-2-one-9-carboxylate $[(3 S, 5 S, 6 S, 9 S)-8$ and $(3 S, 6 S, 7 S, 9 S)-9]$

A solution of $\left(1^{\prime} R, 5 S\right)-1^{\prime}$-iodo-tetrahydrofuran-2-one $\left(1^{\prime} R, 5 S\right)-16(1.0 \mathrm{~g}, 1.8 \mathrm{mmol})$ in dichloromethane $(20 \mathrm{~mL})$ was treated with $\mathrm{HCl}$ gas bubbles for $2-3 \mathrm{~h}$, when TLC indicted complete consumption of the starting carbamate and LCMS analysis indicated a new peak $\mathrm{RT}=0.7 \mathrm{~min}\left(\mathrm{C} 18\right.$ column, $\left.10: 90 \mathrm{CH}_{3} \mathrm{CN}: \mathrm{H}_{2} \mathrm{O}\right)$ with a molecular ion of $[\mathrm{M}+\mathrm{H}]^{+} \mathrm{m} / z 357$. The reaction mixture was evaporated to a residue, which was dissolved in $\mathrm{MeOH}(5 \mathrm{~mL})$, treated with triethylamine (545 mg, $5.4 \mathrm{mmol}, 3$ equiv.), and heated at reflux using an oil bath overnight, when LCMS indicated a new peak RT $=0.68$ min (eluent C18 column, 10:90 $\mathrm{CH}_{3} \mathrm{CN}: \mathrm{H}_{2} \mathrm{O}$ ) with the molecular ion $[\mathrm{M}+\mathrm{H}]^{+} \mathrm{m} / \mathrm{z}$. The volatiles were evaporated under reduced pressure. The residue was dissolved in dichloromethane $(10 \mathrm{~mL})$, treated with (Boc) $)_{2} \mathrm{O}(0.14 \mathrm{~g}, 0.63 \mathrm{mmol}, 1.2$ equiv.), and stirred for $3 \mathrm{~h}$, when TLC indicated two new spots and LCMS indicated a new peak RT $=5.0 \mathrm{~min}\left(\mathrm{C} 18\right.$ column, 10:90 $\left.\mathrm{CH}_{3} \mathrm{CN}: \mathrm{H}_{2} \mathrm{O}\right)$. The volatiles were removed under reduced pressure. The residue was purified by flash column chromatography using 60-80\% EtOAc in hexanes as eluent.<smiles>COC(=O)[C@@H]1CC[C@H]2[C@H](O)C[C@@H](NC(=O)OCc3ccccc3)C(=O)N12</smiles>

(3S,5S,6S,9S)-8<smiles>COC(=O)[C@@H]1C[C@@H](O)[C@H]2CC[C@H](N=C(O)c3ccccc3)C(=O)N12</smiles>

(3S,6S,7S,9S)-9

The first to elute was Boc-(7-HO)I²aa-OMe (3S,6S,7S,9S)-9 (200 mg, 34\%) as a white solid: $\mathrm{mp} 138-140{ }^{\circ} \mathrm{C} ; \mathrm{R}_{f}=0.47$, (100\% EtOAc twice eluted, visualized with $\left.\mathrm{KMnO}_{4}\right)$; $[\alpha]_{\mathrm{D}}{ }^{25}-28.2\left(c \mathrm{c} 0.85, \mathrm{CHCl}_{3}\right) ;{ }^{1} \mathrm{H} \mathrm{NMR}\left(500 \mathrm{MHz}, \mathrm{CDCl}_{3}\right) \delta 5.14$ (s, br, NH), 4.46-4.44 (dd, $J=10 \mathrm{~Hz}, 1 \mathrm{H}), 4.22-4.18(\mathrm{~m}, 1 \mathrm{H}), 4.15-4.12(\mathrm{~m}, 1 \mathrm{H}), 3.84(\mathrm{~s}, 3 \mathrm{H}), 3.76-3.71(\mathrm{~m}, 1 \mathrm{H}), 3.61-3.58$ $(\mathrm{d}, J=15 \mathrm{~Hz}, \mathrm{OH}), 2.4-2.33(\mathrm{~m}, 2 \mathrm{H}), 2.29-2.22(\mathrm{~m}, 1 \mathrm{H}), 2.15-2.12(\mathrm{dt}, J=14.5,0.9 \mathrm{~Hz}, 1 \mathrm{H})$, 2.0-1.93 (m, 1H), 1.77-1.69 (m, 1H), $1.47(\mathrm{~s}, 9 \mathrm{H}) ;{ }^{13} \mathrm{C}\left\{{ }^{1} \mathrm{H}\right\}$ NMR $\left(125 \mathrm{MHz}, \mathrm{CDCl}_{3}\right) \delta 175.5$, 170.1, 156.0, 80.0, 73.0, 61.5, 57.1, 53.2, 51.0, 36.3, 28.3, 27.1, 19.2; FT-IR (neat) $v_{\max } 3357$, 2979, 1693, 1636, 1518, 1437, 1392, 1365, 1249, 1165, 1099, 1063, $1005 \mathrm{~cm}^{-1}$ HRMS (ESI-TOF) $m / z[\mathrm{M}+\mathrm{Na}]^{+}$calcd for $\mathrm{C}_{15} \mathrm{H}_{24} \mathrm{~N}_{2} \mathrm{O}_{6} \mathrm{Na} 351.1526$ found 351.1522 .

Next to elute was Boc-(5-HO) $\mathrm{I}^{2}$ aa-OMe $(3 S, 5 S, 6 S, 9 S)-8(250 \mathrm{mg}, 42 \%)$ as a white solid: mp $75-77{ }^{\circ} \mathrm{C} ; \mathrm{R}_{f}=0.3\left(100 \%\right.$ EtOAc, twice eluted, visualized with $\left.\mathrm{KMnO}_{4}\right) ;[\alpha]_{\mathrm{D}}{ }^{25}-12.6$ (c $\left.0.75, \mathrm{CHCl}_{3}\right) .{ }^{1} \mathrm{H}$ NMR $\left(500 \mathrm{MHz}, \mathrm{CDCl}_{3}\right) \delta 5.25$ (s, br, NH), 4.50-4.44 (m, 2H), 4.27 (s, $1 \mathrm{H}), 3.89-3.86(\mathrm{~m}, 1 \mathrm{H}), 3.77(\mathrm{~s}, 3 \mathrm{H}), 2.74-2.68(\mathrm{~m}, 1 \mathrm{H}), 2.44-2.40(\mathrm{~m}, 1 \mathrm{H}), 2.11-2.04(\mathrm{~m}, 2 \mathrm{H})$, 2.00-1.97 (m, 1H), 1.95-1.92 (m, 1H), 1.88-1.83 (m, 1H), $1.45(\mathrm{~s}, 9 \mathrm{H}) ;{ }^{13} \mathrm{C}\left\{{ }^{1} \mathrm{H}\right\}$ NMR $(125$ $\left.\mathrm{MHz}_{2} \mathrm{CDCl}_{3}\right) \delta 173.0,168.0,156.2,80.0,64.0,63.3,58.2,52.3,47.4,36.0,28.3,28.0,27.0$; FT-IR (neat) $v_{\max } 3360,2983,1702,1633,1518,1438,1395,1250,1162,1102,1002 \mathrm{~cm}^{-1}$; HRMS (ESI-TOF) $m / z[\mathrm{M}+\mathrm{Na}]^{+}$calcd for $\mathrm{C}_{15} \mathrm{H}_{24} \mathrm{~N}_{2} \mathrm{O}_{6} \mathrm{Na} 351.1526$ found 351.1522 . 


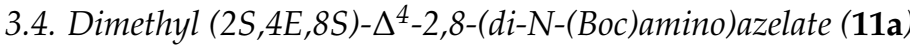

In a 250-mL round bottom flask, fitted with a three-way stopcock, CuBrøDMS (1.22 g, 0.006 mol, 0.13 equiv.) was weighed, dried gently with a heat gun under vacuum until the powder changed color from white to light green, placed under argon, treated with dry DMF (30 mL), followed by (E)-1,3-dichloroprop-1-ene ( $2.5 \mathrm{~g}, 0.023 \mathrm{~mol}, 0.5$ equiv.). In a Schlenk tube, zinc ( $8.9 \mathrm{~g}, 0.14 \mathrm{~mol}, 3$ equiv.) and iodine $(0.35 \mathrm{~g}, 0.0014 \mathrm{~mol}, 0.03$ equiv.) were mixed under an argon atmosphere, and thrice heated under vacuum with a heat gun for $10 \mathrm{~min}$ and cooled under a flush of argon. A solution of $\mathrm{N}$-(Boc)-3-iodo-L-alanine methyl ester 10a $(15 \mathrm{~g}, 0.046 \mathrm{~mol})$ in dry DMF $(30 \mathrm{~mL})$ was added to the Schlenk tube and stirred for $1 \mathrm{~h}$, when TLC analysis confirmed the consumption of the iodide $\left(\mathrm{R}_{f}=0.7\right.$, $30 \%$ EtOAc in hexanes) and formation of the organozinc reagent $\left(R_{f}=0.2,30 \%\right.$ EtOAc in hexanes). Stirring was stopped, the excess zinc powder was allowed to settle, and the supernatant was transferred dropwise via a syringe with care to minimize the transfer of zinc into the flask containing the copper catalyst. After stirring at rt overnight, TLC indicated a new spot $\left(R_{f}=0.48,40 \%\right.$ EtOAc in hexanes $)$ and the reaction mixture was diluted with ethyl acetate $(150 \mathrm{~mL})$, stirred for $15 \mathrm{~min}$, and filtered through a silica gel pad. The filtrate was treated with water $(100 \mathrm{~mL})$, transferred into a separatory funnel, and diluted with ethyl acetate $(50 \mathrm{~mL})$. The organic phase was washed successively with $1 \mathrm{M}$ $\mathrm{Na}_{2} \mathrm{~S}_{2} \mathrm{O}_{3}(2 \times 100 \mathrm{~mL})$, water $(4 \times 100 \mathrm{~mL})$, and brine $(2 \times 100 \mathrm{~mL})$, dried over $\mathrm{Na}_{2} \mathrm{SO}_{4}$, filtered, and evaporated. The volatiles were removed under reduced pressure to afford a residue that was purified by chromatography using 25-30\% EtOAc in hexanes as the eluent. Evaporation of the collected fractions gave azelate $11 \mathrm{a}(11.4 \mathrm{~g}, 56 \%)$ as a colorless liquid: $\mathrm{R}_{f}=0.48\left(2: 3 \mathrm{EtOAc} /\right.$ Hexanes, visualized with $\left.\mathrm{KMnO}_{4}\right) ;[\alpha]_{\mathrm{D}}{ }^{25}+25.2\left(c 1.04, \mathrm{CHCl}_{3}\right) ;{ }^{1} \mathrm{H}$ NMR (500 MHz, CDCl $\left.)_{3}\right) \delta 5.54-5.48(\mathrm{dt}, J=15,5 \mathrm{~Hz}, 1 \mathrm{H}), 5.39-5.34(\mathrm{dt}, J=15,5 \mathrm{~Hz}, 1 \mathrm{H})$, $5.25-5.24(\mathrm{~d}, J=5.0 \mathrm{~Hz}, 1 \mathrm{H}), 5.03-5.01(\mathrm{~d}, J=10 \mathrm{~Hz}, 1 \mathrm{H}), 4.40-4.37(\mathrm{~m}, 1 \mathrm{H}), 4.34-4.30$ $(\mathrm{m}, 1 \mathrm{H}), 3.76(\mathrm{~s}, 3 \mathrm{H}), 3.75(\mathrm{~s}, 3 \mathrm{H}), 2.52-2.43(\mathrm{~m}, 2 \mathrm{H}), 2.12-2.07(\mathrm{~m}, 2 \mathrm{H}), 1.90-1.84(\mathrm{~m}, 1 \mathrm{H})$, 1.71-1.67 (m, 1H), $1.47(\mathrm{~s}, 9 \mathrm{H}), 1.46(\mathrm{~s}, 9 \mathrm{H}) ;{ }^{13} \mathrm{C}\left\{{ }^{1} \mathrm{H}\right\}\left(125 \mathrm{MHz}, \mathrm{CDCl}_{3}\right) \delta$ 173.3, 173.0, 155.3, 155.2, 133.1, 125.5, 79.95, 79.84, 53.2, 53.0, 52.3, 52.2, 35.6, 32.4, 28.4, 28.3, 23.2; FT-IR (neat) $v_{\max } 3363,2977,1698,1508,1437,1391,1365,1247,1211,1157,1103,1050,1021 \mathrm{~cm}^{-1}$; HRMS (ESI-TOF) $m / z[\mathrm{M}+\mathrm{Na}]^{+}$calcd for $\mathrm{C}_{21} \mathrm{H}_{36} \mathrm{~N}_{2} \mathrm{O}_{8} \mathrm{Na} 467.2363$ found 467.2359 .

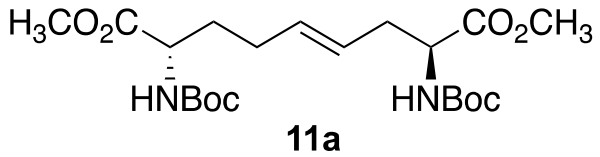

\subsection{Dimethyl (2S,4E,8S)- $\Delta^{4}-2,8-($ di-N-(Cbz)amino)azelate (11b)}

Diamino azelate $\mathbf{1 1 b}$ with $\mathrm{Cbz}$ protection was synthesized according to the protocol described for the synthesis of Boc counterpart 11a using $\mathrm{N}$-(Cbz)-3-iodo-L-alanine methyl ester $10 \mathrm{~b}(8.0 \mathrm{~g}, 0.02 \mathrm{mmol})$ and isolated as a colorless liquid $(3.5 \mathrm{~g}, 63 \%): \mathrm{R}_{f}=0.30(2: 3$ E.A/Hexanes, visualized by UV); $[\alpha]_{\mathrm{D}}{ }^{25}+15.9\left(\mathrm{c} 1.09, \mathrm{CHCl}_{3}\right) ;{ }^{1} \mathrm{H} \mathrm{NMR}\left(500 \mathrm{MHz}, \mathrm{CD}_{3} \mathrm{OD}\right)$ : $\delta 7.40-7.31(\mathrm{~m}, 10 \mathrm{H}), 5.57-5.55(\mathrm{~d}, J=10 \mathrm{~Hz}, 1 \mathrm{H}), 5.52-5.45(\mathrm{dt}, J=15,5 \mathrm{~Hz}, 1 \mathrm{H}), 5.38-5.33$ $(\mathrm{dt}, J=15,5 \mathrm{~Hz}, 1 \mathrm{H}), 5.29-5.27(\mathrm{~d}, J=10 \mathrm{~Hz}, 1 \mathrm{H}), 5.16-5.11(\mathrm{~m}, 4 \mathrm{H}), 4.48-4.44(\mathrm{~m}, 1 \mathrm{H})$, 4.42-4.37 (m, 1H), $3.76(\mathrm{~s}, 3 \mathrm{H}), 3.75(\mathrm{~s}, 3 \mathrm{H}) 2.58-2.46(\mathrm{~m}, 2 \mathrm{H}), 2.13-2.01(\mathrm{~m} 2 \mathrm{H}), 1.94-1.82(\mathrm{~m}$, $1 \mathrm{H}), 1.74-1.67(\mathrm{~m}, 1 \mathrm{H}) ;{ }^{13} \mathrm{C}\left\{{ }^{1} \mathrm{H}\right\} \mathrm{NMR}\left(125 \mathrm{MHz}, \mathrm{CDCl}_{3}\right) \delta 172.2,156.0,136.2,132.3,128.57$, $128.54,128.52,128.46,128.25,128.22,128.16,128.13,125.32,67.1,67.0,54.0,53.0,52.4,52.3$, 35.4, 32.4, 32.2, 28.2; FT-IR (neat) $v_{\max } 3332,2953,1699,1521,1437,1341,1207,1050 \mathrm{~cm}^{-1}$; HRMS (ESI-TOF) $m / z$ [M + H] $]^{+}$calcd for $\mathrm{C}_{27} \mathrm{H}_{33} \mathrm{~N}_{2} \mathrm{O}_{8}$ 513.2231, found 513.2234.

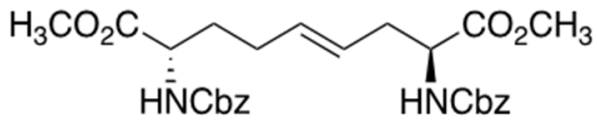




\subsection{Dimethyl (2S,4RS,5RS,8S)-2,8-di-N-(Boc)amino-4-oxiranyl-azelate (12a)}

A solution of $\Delta^{4}$-di- $N$-(Boc)aminoazelate 11a $(2.0 \mathrm{~g}, 4.5 \mathrm{mmol})$ in dichloromethane (DCM, $30 \mathrm{~mL})$ was cooled to $0{ }^{\circ} \mathrm{C}$ and treated with $m$-chloroperoxybenzoic acid $(2.0 \mathrm{~g}$, $9.0 \mathrm{mmol}, 2.0$ equiv.). The ice bath was removed. The suspension was warmed to room temperature with stirring overnight, when TLC showed the complete consumption of olefin 11a $\left(R_{f}=0.48,40 \%\right.$ EtOAc in hexanes $)$ and a new polar spot for epoxide $12 a\left(R_{f}=0.2,40 \%\right.$ EtOAc in hexanes). The reaction mixture was diluted with DCM $(30 \mathrm{~mL})$, transferred to a separatory funnel, and washed sequentially with $1 \mathrm{~N} \mathrm{NaOH}(2 \times 20 \mathrm{~mL})$, water $(20 \mathrm{~mL})$, and brine $(20 \mathrm{~mL})$, dried over $\mathrm{Na}_{2} \mathrm{SO}_{4}$, filtered, and concentrated under vacuum to a residue that was purified by flash column chromatography using $20 \%$ EtOAc in hexanes as the eluent. Evaporation of the collected fractions afforded epoxide $20 \mathrm{a}(1.75 \mathrm{~g}, 84 \%)$ as colorless oil: $\mathrm{R}_{f}=0.2\left(2: 3 \mathrm{EtOAc} /\right.$ hexanes, visualized with $\left.\mathrm{KMnO}_{4}\right) ;[\alpha]_{\mathrm{D}}{ }^{25}+2.5\left(c 0.81, \mathrm{CHCl}_{3}\right) ;{ }^{1} \mathrm{H}$ NMR (500 MHz, CD 3 OD): $\delta 4.32-4.26(\mathrm{~m}, 1 \mathrm{H}), 4.18-4.13(\mathrm{~m}, 1 \mathrm{H}), 3.75(\mathrm{~s}, 3 \mathrm{H}), 3.74(\mathrm{~s}, 3 \mathrm{H})$, 2.87-2.75 (m, 2H), 1.97-1.90 (m, 2H), 1.80-1.72 (m, 1H), 1.64-1.59 (m, 1H), $1.47(\mathrm{~s}, 20 \mathrm{H})$; $\left.{ }^{13} \mathrm{C}^{1}{ }^{1} \mathrm{H}\right\}$ NMR $\left(125 \mathrm{MHz}, \mathrm{CD}_{3} \mathrm{OD}\right) \delta 173.2,173.0,156.7,156.6,79.4,79.2,58.0,57.5,55.4$, 55.3, 53.5, 53.1, 51.51, 51.4, 51.3, 34.0, 27.3; FT-IR (neat) $v_{\max }$ 3326, 2955, 1699, 1523, 1437, $1210,1045,912 \mathrm{~cm}^{-1}$; HRMS (ESI-TOF) $m / z$ [M + Na] ${ }^{+}$calcd for $\mathrm{C}_{21} \mathrm{H}_{36} \mathrm{~N}_{2} \mathrm{O}_{9} \mathrm{Na} 483.2313$, found 483.2321 .<smiles></smiles>

\subsection{Dimethyl (2S,4RS,5RS,8S)-2,8-di-N-(Cbz)amino-4-oxiranyl-azelate (12b)}

Epoxide 12b with $\mathrm{Cbz}$ protection was synthesized using the protocol described for the preparation of Boc counterpart 12a using dimethyl $\Delta^{4}$-di-(Cbz)amino azelate $\mathbf{1 1 b}$ ( $3.2 \mathrm{~g}$, $6.2 \mathrm{mmol})$ and isolated as a colorless liquid $(2.5 \mathrm{~g}, 76 \%): \mathrm{R}_{f}=0.21$ (2:3 EtOAc/hexanes, visualized by UV); $[\alpha]_{\mathrm{D}}{ }^{25}+7.95$ (c $\left.0.88, \mathrm{CHCl}_{3}\right) ;{ }^{1} \mathrm{H} \mathrm{NMR}\left(500 \mathrm{MHz}, \mathrm{CDCl}_{3}\right): \delta 7.40-7.33$ $(\mathrm{m}, 10 \mathrm{H}), 5.68-5.62(\mathrm{~d}, J=10 \mathrm{~Hz}, 1 \mathrm{H}), 5.44-5.32(\mathrm{~d}, J=5 \mathrm{~Hz}, 1 \mathrm{H}), 5.16-5.11(\mathrm{~m}, 4 \mathrm{H}), 4.58-4.11$ $(\mathrm{m}, 1 \mathrm{H}), 4.45-4.39(\mathrm{~s}, 1 \mathrm{H}), 3.79-3.76(\mathrm{~s}, 6 \mathrm{H}), 2.81-2.70(\mathrm{~m}, 2 \mathrm{H}), 2.25-2.07(\mathrm{~m}, 1 \mathrm{H}), 2.04-1.92$ $(\mathrm{m}, 2 \mathrm{H}), 1.83-1.75(\mathrm{~m}, 1 \mathrm{H}), 1.71-1.65(\mathrm{~m}, 1 \mathrm{H}), 1.54-1.44(\mathrm{~m}, 1 \mathrm{H}) ;{ }^{13} \mathrm{C}\left\{{ }^{1} \mathrm{H}\right\}$ NMR $(125 \mathrm{MHz}$, $\left.\mathrm{CDCl}_{3}\right) \delta 172.5,172.1,156.0,136.2,128.6,128.3,128.2,67.1,57.5,55.3,55.1,53.5,53.2,53.0$, $52.65,52.57,52.51,52.2,35.0,30.0,29.0,28.0,27.5$; FT-IR (neat) $v_{\max } 3332,2953,1700,1521$, $1437,1344,1208,1049 \mathrm{~cm}^{-1}$; HRMS (ESI-TOF) $\mathrm{m} / z[\mathrm{M}+\mathrm{H}]^{+}$calcd for $\mathrm{C}_{27} \mathrm{H}_{33} \mathrm{~N}_{2} \mathrm{O}_{9} 529.2180$, found 529.2190 .

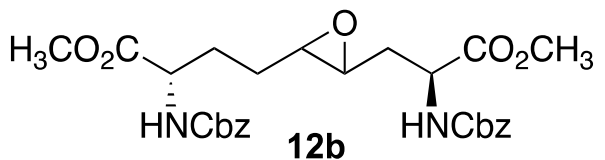

\subsection{Dimethyl (2S,4RS,5RS,8S)-2,8-di-N-(Fmoc)amino-4-oxiranyl-azelate (12c)}

Dimethyl (2S,4E,8S)- $\Delta^{4}-2,8-($ di- $N$-(Fmoc)amino)azelate (11c) was synthesized using the protocol described for the synthesis of $\Delta^{4}$-di-(Boc)amino azelate 11a from $N$-(Fmoc)3-iodo-L-alanine methyl ester (10c, $1.5 \mathrm{~g}, 0.0022 \mathrm{~mol}$ ) and isolated as a colorless liquid $(0.7 \mathrm{~g}, 63 \%): \mathrm{R}_{f}=0.21$ (4:6 ethyl acetate/hexanes, visualized by UV). Epoxidation was performed as described for Boc counterpart 11a using dimethyl $(2 S, 4 E, 8 S)-\Delta^{4}-2,8-(\mathrm{di}-\mathrm{N}$ (Fmoc)amino)azelate (11c, $600 \mathrm{mg}, 0.87 \mathrm{mmol})$, which gave a colorless solid (500 mg, 82\%): $\mathrm{mp} 89-92{ }^{\circ} \mathrm{C} ; \mathrm{R}_{f}=0.30\left(4: 6 \mathrm{EtOAc} /\right.$ hexanes, visualized by UV); $[\alpha]_{\mathrm{D}}{ }^{25}+5.5\left(c \quad 0.51, \mathrm{CHCl}_{3}\right)$; ${ }^{1} \mathrm{H}$ NMR $\left(500 \mathrm{MHz}, \mathrm{CDCl}_{3}\right): 87.79-7.77(\mathrm{~d}, J=10 \mathrm{~Hz}, 4 \mathrm{H}) 7.63-7.57(\mathrm{~m}, 4 \mathrm{H}), 7.43-7,40(\mathrm{~m}$, $4 \mathrm{H}), 7.34-7.31(\mathrm{~m}, 4 \mathrm{H}), 5.74-5.67(\mathrm{dd}, J=10,5 \mathrm{~Hz}, 1 \mathrm{H}), 5.48-5.34(\mathrm{dd}, J=12,10 \mathrm{~Hz}, 1 \mathrm{H})$, $4.60-4.51(\mathrm{~m}, 2 \mathrm{H}), 4.46-4.40(\mathrm{~m}, 4 \mathrm{H}), 4.26-4.22(\mathrm{~m}, 2 \mathrm{H}), 3.81(\mathrm{~s}, 3 \mathrm{H}), 3.78(\mathrm{~s}, 3 \mathrm{H}), 2.85-2.73$ $(\mathrm{m}, 2 \mathrm{H}), 2.16-1.74(\mathrm{~m}, 6 \mathrm{H}) ;{ }^{13} \mathrm{C}\left\{{ }^{1} \mathrm{H}\right\} \mathrm{NMR}\left(125 \mathrm{MHz}, \mathrm{CDCl}_{3}\right) \delta 172.6,172.1,156.0,143.8$, 
$143.7,141.3,130.0,128.0,127.1,125.1,120.0,67.2,67.1,67.0,57.4,55.3,55.1,53.2,52.73,52.7$, 52.6, 52.5, 47.1, 35.0, 30.0, 28.97, 28.9, 27.6, 27.5; FT-IR (neat) $v_{\max } 3290,2952,1690,1531$, $1448,1260,1215,1085,1045 \mathrm{~cm}^{-1}$; HRMS (ESI-TOF) $m / z[\mathrm{M}+\mathrm{H}]^{+}$calcd for $\mathrm{C}_{41} \mathrm{H}_{41} \mathrm{~N}_{2} \mathrm{O}_{9}$ 705.2806, found 705.2819.<smiles>COC(=O)C(CCC1OC1CC[C@H](N=[N+]=O)C(=O)O[Na])C(=O)OC</smiles>

\section{9. (2. $S, 4 E, 8 S)-\Delta^{4}-2,8-(d i-N-(B o c) a m i n o) a z e l i c$ Acid (19)}

A $0{ }^{\circ} \mathrm{C}$ solution of dimethyl $(2 S, 4 E, 8 S)-\Delta^{4}-2,8-($ di- $N$-(Boc)amino)azelate (11a, $500 \mathrm{mg}$, $1.12 \mathrm{mmol})$ in 1,4-dioxane $(5 \mathrm{~mL})$ was treated with a $1 \mathrm{~N}$ solution of $\mathrm{LiOH}(94.4 \mathrm{mg}$, $2.25 \mathrm{mmol}, 2$ equiv.). The cooling bath was removed. The reaction mixture was warmed to room temperature with stirring for $3 \mathrm{~h}$, at which time TLC indicated the consumption of the starting material. The volatiles were evaporated under reduced pressure. The residue was partitioned between $\mathrm{H}_{2} \mathrm{O}(10 \mathrm{~mL})$ and EtOAc $(5 \mathrm{~mL})$. The aqueous phase was acidified with $1 \mathrm{~N} \mathrm{HCl}$ to $\mathrm{pH} 3$ and extracted with ethyl acetate $(3 \times 10 \mathrm{~mL})$. The organic extractions were combined, dried with $\mathrm{Na}_{2} \mathrm{SO}_{4}$, filtered, and concentrated under vacuum to afford diacid 19 (430 mg, 92\%) as a white solid: $\mathrm{mp} 71-73{ }^{\circ} \mathrm{C}$; $[\alpha]_{\mathrm{D}}{ }^{25}+39.0\left(c 0.82, \mathrm{CHCl}_{3}\right) ;{ }^{1} \mathrm{H}$ NMR (500 MHz, DMSO- $\left.d_{6}\right): \delta 12.42(\mathrm{~s}, 2 \mathrm{H}), 7.08-7.07(\mathrm{~d}, J=5.0 \mathrm{~Hz}, 1 \mathrm{H}), 6.97-6.96(\mathrm{~d}, J=5 \mathrm{~Hz}$, $1 \mathrm{H}), 5.50-5.44(\mathrm{~m}, 1 \mathrm{H}), 5.40-5.35(\mathrm{~m}, 1 \mathrm{H}), 3.90-3.84(\mathrm{~m}, 2 \mathrm{H}), 2.37-2.32(\mathrm{~m}, 1 \mathrm{H}), 2.29-2.23(\mathrm{~m}$, 1H), $1.71-1.50(\mathrm{~m}, 4 \mathrm{H}), 1.39(\mathrm{~s}, 9 \mathrm{H}), 1.38(\mathrm{~s}, 9 \mathrm{H}) ;{ }^{13} \mathrm{C}\left\{{ }^{1} \mathrm{H}\right\}$ NMR $(125 \mathrm{MHz}$, DMSO-d $) \delta 175.0$, 174.0, 156.03, 155.88, 132.2, 127.0, 78.47, 78.41, 60.2, 54.1, 53.3, 34.5, 31.1, 28.68, 28.66; FT-IR (neat) $v_{\max } 3697,2980,1694,1507,1393,1367,1245,1157,1053,1033,1018 \mathrm{~cm}^{-1}$; HRMS (ESI-TOF) $m / z[\mathrm{M}+\mathrm{Na}]^{+}$calcd for $\mathrm{C}_{19} \mathrm{H}_{32} \mathrm{~N}_{2} \mathrm{O}_{8} \mathrm{Na} 439.2050$, found 439.2070.<smiles>CC(C)(C)OC(=O)N[C@@H](N)CC/C=C/CC(C(=O)O)C(=O)O</smiles>

19

3.10. ( $\left.1^{\prime} R, 5 S\right)-3-N-(B o c)$ amino-5-[1'-iodo- $4^{\prime}-N-($ Boc $)$ amino- $\left.4^{\prime}-m e t h o x c a r b o n y l b u t y l\right]-$ tetrahydrofuran-2-one $\left[\left(1^{\prime} R, 5 S\right)-16\right]$

A $0{ }^{\circ} \mathrm{C}$ mixture of carboxylic acid $\left(1^{\prime} R, 5 S\right)-20(2.1 \mathrm{~g}, 3.87 \mathrm{mmol})$ and $\mathrm{K}_{2} \mathrm{CO}_{3}(800 \mathrm{mg}$ $5.8 \mathrm{mmol}, 1.5$ equiv.) in DMF (20 mL) was treated with methyl iodide $(820 \mathrm{mg}, 5.8 \mathrm{mmol}$, 1.5 equiv.). The ice bath was removed. After stirring for $2-3 \mathrm{~h}$, the room temperature mixture exhibited a nonpolar spot (2:3 EtOAc/hexanes) by TLC and indicated a new peak at $\mathrm{RT}=9.0 \mathrm{~min}\left(\mathrm{C} 18\right.$ column, 10:90 $\left.\mathrm{CH}_{3} \mathrm{CN}: \mathrm{H}_{2} \mathrm{O}\right)$ by LCMS analysis, with a molecular ion of $[\mathrm{M}+\mathrm{Na}]^{+} m / z 579$. The reaction mixture was diluted with water and extracted with ethyl acetate $(4 \times 50 \mathrm{~mL})$. The ethyl acetate layer was washed with water $(4 \times 50 \mathrm{~mL})$ and brine $(2 \times 30 \mathrm{~mL})$, dried over $\mathrm{Na}_{2} \mathrm{SO}_{4}$, filtered, and concentrated under reduced pressure. The residue was purified by flash column chromatography using 20-30\% EtOAc in hexanes as the eluent. Evaporation of the collected fractions gave tetrahydrofuran-2-one $\left(1^{\prime} R, 5 S\right)-16(1.1 \mathrm{~g}, 55 \%$ from diacid 19$)$ as a colorless solid: $\mathrm{mp} 58-60{ }^{\circ} \mathrm{C} ; \mathrm{R}_{f}=0.56(2: 3$ $\mathrm{EtOAc} /$ hexanes, visualized by $\left.\mathrm{KMnO}_{4}\right),[\alpha]_{\mathrm{D}}{ }^{25}+13.4\left(c 0.68, \mathrm{CHCl}_{3}\right) ;{ }^{1} \mathrm{H} \mathrm{NMR}(500 \mathrm{MHz}$, $\left.\mathrm{CDCl}_{3}\right): \delta 5.10-5.08(\mathrm{~d}, J=10 \mathrm{~Hz}, 2 \mathrm{H}), 4.45-4.41(\mathrm{~m}, 1 \mathrm{H}), 4.37-4.33(\mathrm{~m}, 2 \mathrm{H}), 4.08-4.04(\mathrm{t}$, $J=10 \mathrm{~Hz}, 1 \mathrm{H}), 3.79(\mathrm{~s}, 3 \mathrm{H}), 3.14-3.09(\mathrm{~m}, 1 \mathrm{H}), 2.23-2.17(\mathrm{~m}, 1 \mathrm{H}), 2.11-2.05(\mathrm{~m}, 1 \mathrm{H}), 1.95-1.87$ $(\mathrm{m}, 2 \mathrm{H}), 1.78-1.73(\mathrm{~m}, 1 \mathrm{H}), 1.48(\mathrm{~s}, 9 \mathrm{H}), 1,47(\mathrm{~s}, 9 \mathrm{H}) ;{ }^{13} \mathrm{C}\left\{{ }^{1} \mathrm{H}\right\}$ NMR $\left(125 \mathrm{MHz}, \mathrm{CDCl}_{3}\right) \delta$ 174.0, 173.0, 155.3, 130.0, 81.0, 80.2, 79.2, 53.0, 52.5, 52.0, 38.0, 36.0, 32.3, 32.0, 28.31, 28.27; FT-IR (neat) $v_{\max } 3281,2921,2853,1801,1747,1697,1674,1537,1451,1368,1294,1252,1213$, $1154,1060,1029,1005 \mathrm{~cm}^{-1}$; HRMS (ESI-TOF) $m / z[\mathrm{M}+\mathrm{Na}]^{+}$calcd for $\mathrm{C}_{20} \mathrm{H}_{33} \mathrm{IN}_{2} \mathrm{O}_{8} \mathrm{Na}$ 579.1173 , found 579.1195 . 


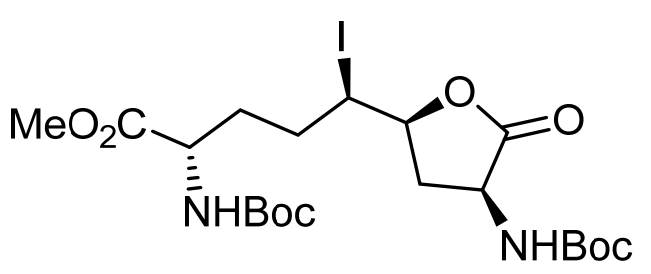

$\left(1^{\prime} R, 5 S\right)-16$

\subsection{1. (1'R,5S)-3-N-(Boc)amino-5-[1'-iodo-4'-N-(Boc)amino-4'-hydroxcarbonylbutyl]- tetrahydrofuran-2-one $\left[\left(1^{\prime} R, 5 S\right)-20\right]$}

A solution of diacid $19(1.6 \mathrm{~g}, 3.8 \mathrm{mmol})$ in acetonitrile $(20 \mathrm{~mL})$ was treated with $\mathrm{Cs}_{2} \mathrm{CO}_{3}\left(3.7 \mathrm{~g}\right.$, $11.5 \mathrm{mmol}, 3$ equiv.), stirred for $15 \mathrm{~min}$, cooled to $0{ }^{\circ} \mathrm{C}$ with an ice bath, and treated with iodine ( $2.93 \mathrm{~g}, 11.5 \mathrm{mmol}, 3$ equiv.). The ice bath was removed. After stirring for 3-4 $\mathrm{h}$, the reaction mixture had warmed to room temperature and was observed by LCMS to contain a new peak at $\mathrm{RT}=8.1 \mathrm{~min}\left(\mathrm{C} 18\right.$ column, $\left.10: 90 \mathrm{CH}_{3} \mathrm{CN}: \mathrm{H}_{2} \mathrm{O}\right)$ with a molecular ion $[\mathrm{M}+\mathrm{Na}]^{+} m / z 565$. The reaction mixture was filtered through a pad of Celite ${ }^{\mathrm{TM}}$ and the filter cake was washed with acetonitrile $(3 \times 30 \mathrm{~mL})$. The filtrate and washings were combined and evaporated under reduced pressure. The residue was partitioned between $\mathrm{H}_{2} \mathrm{O}(50 \mathrm{~mL})$ and EtOAc $(25 \mathrm{~mL})$. The aqueous phase was acidified with $1 \mathrm{~N} \mathrm{HCl}$ to $\mathrm{pH} 3$ and extracted with ethyl acetate $(3 \times 50 \mathrm{~mL})$. The organic extractions were combined, dried with $\mathrm{Na}_{2} \mathrm{SO}_{4}$, filtered, and concentrated under vacuum to afford tetrahydrofuran-2-one $\left(1^{\prime} R, 5 S\right)-20(2.1 \mathrm{~g})$ as a pale-yellow solid, which was used without further purification.<smiles>CC(C)(C)OC(=O)N[C@@H](CCC(I)C1CC(NC(=O)OCc2ccccc2)C(=O)O1)C(=O)O</smiles>

20

\section{Conclusions}

The copper catalyzed $\mathrm{S}_{\mathrm{N}} 2^{\prime}$ addition of zincate derived from methyl $\beta$-iodo alaninate onto (E)-1,3-dichloroprop-1-ene has given useful entry into a set of protected $\Delta^{4}$-2,8diaminoazelates (e.g., 11a-c). Attempts to fold the latter linear precursors into bicyclic 5and 7-substituted indolizidin-2-one amino acid ( $\left.\mathrm{I}^{2} \mathrm{aa}\right)$ derivatives have, however, demonstrated the challenges of achieving diastereomeric and regioisomeric selectivity in the facial differentiation of the olefin. Epoxidation and dihydroxylation were unselective and gave oxiranes $\mathbf{1 2}$ and hydroxy lactone $\mathbf{1 7}$ as inseparable mixtures of diastereomers, which were shown by LCMS analyses to be convertible into mixtures of up to four hydroxy indolizidine2-one isomers due in part to the inability to control the intramolecular cyclization of the respective nitrogen. Moreover, diastereomeric stereochemical integrity may have also been lost due to cyclization by way of planar $\mathrm{S}_{\mathrm{N}} 1$ intermediates.

Iodolactonization of $\Delta^{4}$-2,8-diaminoazelic diacid 19 occurred with high facial selectivity to provide tetrahydrofuran-2-one $\left(1^{\prime} R, 5 S\right)-\mathbf{1 6}$ as a single isomer. Both nitrogen of iodide 16 reacted in intramolecular $S_{N} 2$ displacements to respectively provide hydroxyproline and proline intermediates. Lactam formation provided 5- and 7-hydroxy indolizidin-2-one amino esters $(3 S, 5 S, 6 S, 9 S)-8$ and $(3 S, 6 S, 7 S, 9 S)-9$ in six steps and $21 \%$ and $17 \%$ respective overall yields from $\Delta^{4}$-2,8-diaminoazelate 11a. Saponification of the esters $(3 S, 5 S, 6 S, 9 S)-8$ and $(3 S, 6 S, 7 S, 9 S)-9$ delivered the corresponding carboxylic acids, which are suitable for peptide synthesis.

The configuration of 5- and 7-hydroxy indolizidin-2-one amino esters (3S,5S,6S,9S)-8 and $(3 S, 6 S, 7 S, 9 S)-9$ was assigned using a series of NMR experiments. Furthermore, $X-$ ray analysis of ester $(3 S, 6 S, 7 S, 9 S)-3$ demonstrated that the backbone geometry within the 
7-hydroxy indolizidine-2-one framework replicated that of the parent $\mathrm{I}^{2}$ aa ester (6S)-21 and mimicked the dihedral angles of the central dipeptide in a type II' $\beta$-turn. The utility of 5- and 7-hydroxy indolizidin-2-one amino acids (3S,5S,6S,9S)-2 and (3S,6S,7S,9S)-3 is currently being investigated inside biologically relevant peptides and will be reported in due time.

Supplementary Materials: The following supporting information can be downloaded, characterization data including ${ }^{1} \mathrm{H}$ and ${ }^{13} \mathrm{C}$ NMR spectra and X-ray coordinates.

Author Contributions: Conceptualization, methodology, validation, formal analysis, investigation, resources, writing — original draft preparation, writing — review and editing, all R.M. and W.D.L.; supervision, project administration, funding acquisition, all W.D.L. All authors have read and agreed to the published version of the manuscript.

Funding: The Natural Sciences and Engineering Research Council of Canada (NSERC) for Discovery Research Project (No. 04079), the Canadian Institutes of Health Research (CIHR), and the NSERCCIHR for the Collaborative Health Research Project "Treatment of Preterm Birth with ProstaglandinF2alpha Receptor Modulators" No. 337381.

Data Availability Statement: CCDC 2125339 contains the supplementary crystallographic data for this paper. These data can be obtained free of charge via www.ccdc.cam.ac.uk/data_request/ cif (accessed on 20 December 2021), or by emailing data_request@ccdc.cam.ac.uk (accessed on 20 December 2021), or by contacting The Cambridge Crystallographic Data Centre, 12 Union Road, Cambridge CB2 1EZ, UK; fax: +44-1223-336033.

Acknowledgments: We acknowledge the assistance of members of the Université de Montréal facilities: A. Fürtös, K. Gilbert, M.-C. Tang, and L. Mahrouche (mass spectrometry), C. Malveau, P. Aguiar (NMR spectroscopy), and T. Maris, D. Chartrand (X-ray).

Conflicts of Interest: The authors declare no conflict of interest.

Sample Availability: Samples of the compounds are not available from the authors.

\section{References}

1. Hanessian, S.; McNaughton-Smith, G.; Lombart, H.G.; Lubell, W.D. Design and synthesis of conformationally constrained amino acids as versatile scaffolds and peptide mimetics. Tetrahedron 1997, 53, 12789-12854. [CrossRef]

2. Sanchez, C.A.; Gadais, C.; Chaume, G.; Girard, S.; Chelain, E.; Brigaud, T. Enantiopure 5-CF3-Proline: Synthesis, Incorporation in Peptides, and Tuning of the Peptide Bond Geometry. Org. Lett. 2021, 23, 382-387. [CrossRef] [PubMed]

3. Beausoleil, E.; Lubell, W.D. Steric Effects on the Amide Isomer Equilibrium of Prolyl Peptides. Synthesis and Conformational Analysis of N-Acetyl-5-tert-butylproline N'-Methylamides. J. Am. Chem. Soc. 1996, 118, 12902-12908. [CrossRef]

4. Bowles, M.; Proulx, C. Solid phase submonomer azapeptide synthesis. In Synthetic and Enzymatic Modifications of the Peptide Backbone; James Petersson, E., Ed.; Methods in Enzymology; Elsevier Inc.: Amsterdam, The Netherlands, 2021; Chapter 6; Volume 656, pp. 169-190. [CrossRef]

5. Hamdane, Y.; Chauhan, P.S.; Vutla, S.; Mulumba, M.; Ong, H.; Lubell, W.D. 5-Substituted N-Aminoimidazolone Peptide Mimic Synthesis by Organocatalyzed Reactions of Azopeptides and Use in the Analysis of Biologically Active Backbone and Side-Chain Topology. Org. Lett. 2021, 23, 3491-3495. [CrossRef] [PubMed]

6. $\quad$ Freidinger, R.M.; Veber, D.F.; Perlow, D.S.; Brooks, J.R.; Saperstein, R. Bioactive conformation of luteinizing hormone-releasing hormone: Evidence from a conformationally constrained analog. Science 1980, 210, 656-658. [CrossRef]

7. St-Cyr, D.J.; García-Ramos, Y.; Doan, N.D.; Lubell, W.D. Aminolactam, N-Aminoimidazolone, and N-Aminoimdazolidinone Peptide Mimics. In Peptidomimetics I. Topics in Heterocyclic Chemistry; Lubell, W.D., Ed.; Springer: Cham, Switzerland, 2017; Volume 48, pp. 125-175. [CrossRef]

8. Cluzeau, J.; Lubell, W.D. Design, synthesis, and application of azabicyclo [XY 0] alkanone amino acids as constrained dipeptide surrogates and peptide mimics. Pept. Sci. 2005, 80, 98-150. [CrossRef]

9. Khashper, A.; Lubell, W.D. Design, synthesis, conformational analysis and application of indolizidin-2-one dipeptide mimics. Org. Biomol. Chem. 2014, 12, 5052-5070. [CrossRef]

10. Polyak, F.; Lubell, W.D. Rigid dipeptide mimics: Synthesis of enantiopure 5-and 7-benzyl and 5, 7-dibenzyl Indolizidinone amino acids via enolization and alkylation of delta-Oxo alpha, omega-Di-[N-(9-(9-phenylfluorenyl))amino] azelate esters. J. Org. Chem. 1998, 63, 5937-5949. [CrossRef]

11. Polyak, F.; Lubell, W.D. Mimicry of peptide backbone geometry and heteroatomic side-chain functionality: Synthesis of enantiopure indolizidin-2-one amino acids possessing alcohol, acid, and azide functional groups. J. Org. Chem. 2001, 66, 1171-1180. [CrossRef] 
12. Feng, Z.; Lubell, W.D. Synthesis of Enantiopure 7-[3-Azidopropyl]indolizidin-2-one Amino Acid. A Constrained Mimic of the Peptide Backbone Geometry and Heteroatomic Side-Chain Functionality of the Ala-Lys Dipeptide. J. Org. Chem. 2001, 66, 1181-1185. [CrossRef]

13. Wessig, P. An efficient synthesis of bicyclic $\beta$-turn dipeptides via a photochemical key step. Tetrahedron Lett. 1999, 40, 5987-5988. [CrossRef]

14. Sun, H.; Moeller, K.D. Silyl-substituted amino acids: New routes to the construction of selectively functionalized peptidomimetics. Org. Lett. 2002, 4, 1547-1550. [CrossRef] [PubMed]

15. Atmuri, N.P.; Lubell, W.D. Stereo-and Regiochemical Transannular Cyclization of a Common Hexahydro- 1 H-azonine to Afford Three Different Indolizidinone Dipeptide Mimetics. J. Org. Chem. 2019, 85, 1340-1351. [CrossRef] [PubMed]

16. Mir, F.M.; Atmuri, N.P.; Bourguet, C.B.; Fores, J.R.; Hou, X.; Chemtob, S.; Lubell, W.D. Paired utility of aza-amino acyl proline and indolizidinone amino ac-id residues for peptide mimicry: Conception of prostaglandin F2 $\alpha$ receptor allosteric modulators that delay preterm birth. J. Med. Chem. 2019, 62, 4500-4525. [CrossRef] [PubMed]

17. Artale, E.; Banfi, G.; Belvisi, L.; Colombo, L.; Colombo, M.; Manzoni, L.; Scolastico, C. Synthesis of substituted conformationally constrained 6, 5-and 7, 5-fused bicyclic lactams as dipeptide mimics. Tetrahedron 2003, 59, 6241-6250. [CrossRef]

18. Manzoni, L.; Belvisi, L.; Arosio, D.; Civera, M.; Pilkington-Miksa, M.; Potenza, D.; Caprini, A.; Araldi, E.M.; Monferini, E.; Mancino, M. Cyclic RGD-containing functionalized azabicycloalkane peptides as potent integrin antagonists for tumor targeting. ChemMedChem 2009, 4, 615-632. [CrossRef]

19. Hanessian, S.; McNaughton-Smith, G. A versatile synthesis of a $\beta$-turn peptidomimetic scaffold: An approach towards a designed model antagonist of the tachykinin NK-2 receptor. Bioorg. Med. Chem. Lett. 1996, 6, 1567-1572. [CrossRef]

20. Hanessian, S.; Therrien, E.; Granberg, K.; Nilsson, I. Targeting thrombin and factor VIIa: Design, synthesis, and inhibitory activity of functionally relevant indolizidinones. Bioorg. Med. Chem. Lett. 2002, 12, 2907-2911. [CrossRef]

21. Hanessian, S.; Sailes, H.; Munro, A.; Therrien, E. Synthesis of Diversely Functionalized Indolizidinones and Related Bicyclic Lactams Using Intramolecular Grubbs Olefin Metathesis and Dieckmann Condensation. J. Org. Chem. 2003, 68, 7219-7233. [CrossRef]

22. Hanessian, S.; Margarita, R. 1,3-Asymmetric Induction in Dianionic Allylation Reactions of Amino Acid Derivatives-Synthesis of Functionally Useful Enantiopure Glutamates, Pipecolates and Pyroglutamates. Tetrahedron Lett. 1998, 39, 5887-5890. [CrossRef]

23. Dunn, M.J.; Jackson, R.F.; Pietruszka, J.; Turner, D. Synthesis of Enantiomerically Pure Unsaturated. alpha.-Amino Acids Using Serine-Derived Zinc/Copper Reagents. J. Org. Chem. 1995, 60, 2210-2215. [CrossRef]

24. Bartlett, P.A.; Myerson, J. Stereoselective epoxidation of acyclic olefinic carboxylic acids via iodolactonization. J. Am. Chem. Soc. 1978, 100, 3950-3952. [CrossRef]

25. Trost, B.M.; Rudd, M.T. Chemoselectivity of the ruthenium-catalyzed hydrative diyne cyclization: Total synthesis of (+)cylindricine C., D, and E. Org. Lett. 2003, 5, 4599-4602. [CrossRef] [PubMed]

26. Hattori, Y.; Asano, T.; Kirihata, M.; Yamaguchi, Y.; Wakamiya, T. Development of the first and practical method for enantioselective synthesis of 10B-enriched p-borono-L-phenylalanine. Tetrahedron Lett. 2008, 49, 4977-4980. [CrossRef]

27. Ozturk, S.; Forneris, C.C.; Nguy, A.K.; Sorensen, E.J.; Seyedsayamdost, M.R. Modulating OxyB-catalyzed cross-coupling reactions in vancomycin biosynthesis by incorporation of diverse D-Tyr analogues. J. Org. Chem. 2018, 83, 7309-7317. [CrossRef] [PubMed]

28. Krishnamurthy, S.; Arai, T.; Nakanishi, K.; Nishino, N. Epoxy amino acids produced from allylglycines intramolecularly cyclised to yield four stereoisomers of 4-hydroxyproline derivatives. RSC Adv. 2014, 4, 2482-2490. [CrossRef]

29. Krishnamurthy, S.; Venkataprasad, J.; Vagvala, T.C.; Moriguchi, T.; Tsuge, A. $\alpha$-Chymotrypsin and l-acylase aided synthesis of 5-hydroxypipecolic acid via Jacobsen's hydrolytic kinetic resolution of epoxy amino acids. RSC Adv. 2015, 5, 52154-52160. [CrossRef]

30. Hoarau, S.; Fauchere, J.L.; Pappalardo, L.; Roumestant, M.L.; Viallefont, P. Synthesis of enantiomerically pure (2R, $5 S)-$ and $(2 R$, 5R)-5-hydroxypipecolic acid from glycinate schiff bases. Tetrahedron Asymmetry 1996, 7, 2585-2593. [CrossRef]

31. Mulamreddy, R.; Hou, X.; Chemtob, S.; Lubell, W.D. 6-Hydroxymethyl Indolizidin-2-one Amino Acid Synthesis, Conformational Analysis, and Biomedical Application as Dipeptide Surrogates in Prostaglandin-F2 $\alpha$ Modulators. Org. Lett. 2021, 23, $5192-5196$. [CrossRef]

32. Gilmore, K.; Mohamed, R.K.; Alabugin, I.V. The Baldwin rules: Revisedand extended WIREs Comput. Mol. Sci. 2016, 6, 487-514. [CrossRef]

33. Vilotijevic, I.; Jamison, T.F. Synthesis of marine polycy-clic polyethers via endo-selective epoxide-opening cas-cades. Mar. Drugs 2010, 8, 763-809. [CrossRef] [PubMed]

34. Wang, J.; Liang, Y.-L.; Qu, J. Boiling water-catalyzed neutral and selective N-Boc deprotection. Chem. Commun. 2009, 2009, 5144-5146. [CrossRef] [PubMed]

35. Atmuri, A.N.D.; Surprenant, S.; Diarra, S.; Bourguet, C.; Lubell, W.D. "Ring Closing Metathesis/Transannular Cyclization to Azabicyclo[X.Y.0]alknanone Dipeptide Turn Mimics for Biomedical Applications" N. Qvit. Peptide and Peptidomimetic Therapeutics: From Bench to Bedside; Academic Press: Cambridge, MA, USA, 2022; accepted; ISBN 012820141X.

36. Marcotullio, M.C.; Campagna, V.; Sternativo, S.; Costantino, F.; Curini, M. A New, Simple Synthesis of N-Tosyl Pyrrolidines and Piperidines. Synthesis 2006, 2006, 2760. [CrossRef] 
37. Davies, S.G.; Nicholson, R.L.; Price, P.D.; Roberts, P.M.; Russell, A.J.; Savory, E.D.; Smith, A.D.; Thomson, J.E. Iodine-mediated ring-closing iodoamination with concomitant $\mathrm{N}$-debenzylation for the asymmetric synthesis of polyhydroxylated pyrrolidines. Tetrahedron Asymmetry 2009, 20, 758-772. [CrossRef]

38. Liu, G.-Q.; Li, Y.-M. Regioselective (diacetoxyiodo)benzene-promoted halocyclization of unfunctionalized olefins. J. Org. Chem. 2014, 79, 10094-10109. [CrossRef]

39. Reddy Vakiti, J.; Hanessian, S. Total Synthesis and Stereochemical Confirmation of (-)-Olivil, (+)-Cycloolivil, (-)-Alashinols F and G,(+)-Cephafortin A, and Their Congeners: Filling in Biosynthetic Gaps. Org. Lett. 2020, 22, 3345-3350. [CrossRef] [PubMed]

40. Nolsøe, J.M.; Hansen, T.V. Asymmetric iodolactonization: An evolutionary account. Eur. J. Org. Chem. 2014, $2014,3051-3065$. [CrossRef]

41. Kurth, M.J.; Brown, E.G. Double diastereoselection in the iodolactonization of 1,6-heptadiene-4-carboxylic acids. J. Am. Chem. Soc. 1987, 109, 6844-6845. [CrossRef]

42. Mauger, A.; Irreverre, F.; Witkop, B. The stereochemistry of 3-methylproline. J. Am. Chem. Soc. 1966, 88, 2019-2024. [CrossRef]

43. Ashtekar, K.D.; Vetticatt, M.; Yousefi, R.; Jackson, J.E.; Borhan, B. Nucleophile-Assisted Alkene Activation: Olefins Alone Are Often Incompetent. J. Am. Chem. Soc. 2016, 138, 8114-8119. [CrossRef]

44. Ball, J.B.; Alewood, P.F. Conformational constraints: Nonpeptide $\beta$-turn mimics. J. Mol. Recognit. 1990, 3, 55-64. [CrossRef] [PubMed]

45. Lombart, H.-G.; Lubell, W.D. Rigid dipeptide mimetics: Efficient synthesis of enantiopure indolizidinone amino acids. J. Org. Chem. 1996, 61, 9437-9446. [CrossRef] 